\title{
Synthesis, Spectroscopic, X-ray Diffraction and Theoretical Studies of some Novel Nickel(II) Chelates of a Heterocyclic Based Tridentate NNO donor Aroylhydrazone: In vitro DNA Binding and Docking studies
}

\section{Yamuna Nair}

Cochin University of Science and Technology

Francis Joy

Cochin University of Science and Technology

M R Prathapachandra Kurup ( $D$ mrpcusat@gmail.com )

Central University of Kerala https://orcid.org/0000-0002-9434-890X

\section{Savaş Kaya}

Sivas Cumhuriyet University

Goncagül Serdaroğlu

Sivas Cumhuriyet University

\section{Sultan ERKAN}

Sivas Cumhuriyet University

\section{Research Article}

Keywords: Aroylhydrazone, Nickel(II) complex, Hirshfeld surface analaysis, Molecular docking, NBO analysis

Posted Date: October 25th, 2021

DOI: https://doi.org/10.21203/rs.3.rs-1005613/v1

License: (c) (i) This work is licensed under a Creative Commons Attribution 4.0 International License. Read Full License 


\title{
Synthesis, Spectroscopic, X-ray Diffraction and Theoretical Studies of some Novel Nickel(II) Chelates of a Heterocyclic Based Tridentate NNO donor Aroylhydrazone: In vitro DNA Binding and Docking studies
}

\author{
Yamuna Nair ${ }^{\mathrm{a}}$, Francis Joy ${ }^{\mathrm{a}}$, Vinod T. P., Vineetha M. C ${ }^{\mathrm{b}, \mathrm{c}}$, M. R. \\ Prathapachandra Kurup ${ }^{\text {b,d,* }}$, Savaş Kaya ${ }^{\mathrm{e}}$, Goncagül Serdaroğlu, ${ }^{\mathrm{f}}$ Sultan ERKAN ${ }^{\mathrm{e}}$ \\ aDepartment of Chemistry, CHRIST (Deemed to be University), Hosur Road, Bengaluru-560 029, Karnataka, \\ India \\ bDepartment of Applied Chemistry, Cochin University of Science and Technology, Kochi 682022 , \\ Kerala, India \\ ${ }^{\mathrm{c}}$ Department of Chemistry, Sree Kerala Varma College, Thrissur 680 011, Kerala, India \\ ${ }^{\mathrm{d}}$ Department of Chemistry, School of Physical Sciences, Central University of Kerala, Kasaragod 671 320, India \\ ${ }^{e}$ Sivas Cumhuriyet University, Faculty of Science, Department of Chemistry, 58140, Sivas, \\ TURKEY, email: sultanerkan@cumhuriyet.edu.tr \\ ${ }^{e}$ Sivas Cumhuriyet University, Faculty of Science, Department of Chemistry, 58140, Sivas, \\ TURKEY, email: savaskaya@cumhuriyet.edu.tr
}

${ }^{f}$ Sivas Cumhuriyet University, Faculty of Education, Department of Science Education, 58040, Sivas, Turkey

serdaroglu@cumhuriyet.edu.tr

${ }^{*}$ Corresponding author. Tel.: +919895226115

E-mail addresses: mrpcusat@gmail.com,mrp@cukerala.ac.in (M.R.P. Kurup) 


\begin{abstract}
Five new nickel(II) complexes have been synthesised with an NNO donor tridentate aroylhydrazone (HFPB) employing the chloride, nitrate, acetate and perchlorate salts, and all the complexes were physiochemically characterized. Elemental analyses suggested a deprotonated iminolate form of the ligand in four of the complexes, however in one case (2), two aroylhydrazone moieties are binding to the metal centre in the neutral and anionic forms. The structure of the bisligated complex $\mathbf{5}$, characterized using X ray diffraction studies affirmed that the metal has a distorted octahedral $\mathrm{N}_{4} \mathrm{O}_{2}$ coordination environment, with each of the two ligands coordinating through the pyridine nitrogen, imino-hydrazone nitrogen and the deprotonated oxygen of the hydrazone moiety. In order to compare and study the elctronic interactions and stabilities of the metal complexes various quantum chemical parameters were calculated. Moreover, Hirshfeld surface analaysis was carried out for complex $\mathbf{5}$ in order to determine the intermolecular interactions. The biophysical attributes of the ligand and complex $\mathbf{5}$ have been investigated with CT DNA and experimental outcomes show that the Ni(II) complex exhibited higher binding propensity towards DNA as compared to ligand. Furthermore, in order to specifically understand the type of interactions of the meatal complexes with DNA molecular docking studies were carried out. In addition, the electronic and related reactivity behaviors of the ligand and five $\mathrm{Ni}(\mathrm{II})$ complexes were effectuated using B3LYP/6-31++g**/LANL2DZ level. As expected, the obtained results from NBO computations displayed that the resonance interactions ( $\mathrm{n} \rightarrow \pi^{*}$ and $\pi \rightarrow \pi^{*}$ ) play a determinant role in evaluating the chemical attributes of the reported compounds.
\end{abstract}

Keywords: Aroylhydrazone, Nickel(II) complex, Hirshfeld surface analaysis, Molecular docking, NBO analysis

\title{
INTRODUCTION
}

The coordination chemistry of nickel proves to be an outgrowing field which provoked extensive research because of the anomalous behavior of $\mathrm{Ni}$ (II) containing metal complexes [1]. The tetra-coordinated $\mathrm{Ni}$ (II) complexes proved to be promising candidates, with numerous examples possessing several exploitable physical and chemical properties including redox, optical, magnetic, catalytic and electronic activity [2-5]. To explain this, diverse models have been introduced which include solute-solvent interactions, magnetically non-equivalent sites 
in the unit cell, configurational equilibrium and so on [2]. Numerous nickel dependent enzymes are found throughout the natural world and are catalysts in many crucial biosynthetic routes [6]. The reaction mechanism of all the enzymatic reactions proved that the catalytic property of nickel atom present in the active site of an enzyme can be attributed to its redox activity [7]. Moreover, in the hardness to softness scale, $\mathrm{Ni}(\mathrm{II})$ is a borderline element which accounts for the formation of covalent bonds with the nitrogenous bases and phosphate groups of DNA [8]. It is found that nickel atoms covalently bind to the N7 atom in guanine and adenine which proved the strong interactions of nickel-based metal complexes with DNA $[9,10]$. This property of nickel-based complexes is well exploited in the development of pharmacophores which possess antineoplastic properties, which in turn are largely used in cancer therapy.

Aroylhydrazones are polydentate ligands with donor atoms integrated into an aromatic chromophore. They cover a wide range of functions and complexity, and they have been proven to have substantial biological activity, making them significant in a variety of metabolic processes. The hydrazone functional group is undoubtedly inevitable since it has uses in a multitude of areas, from medicinal chemistry to supramolecular chemistry, and has been utilized as a catalyst in a variety of organic syntheses [11]. These compounds are derived from the condensation reaction between hydrazides and carbonyl compounds which includes aldehydes and ketones [12]. Their popularity among the scientific community can be attributed to its simple synthetic procedure, stability towards hydrolysis and modularity [13]. The physical and chemical properties of hydrazones are determined by the azomethine group characterized by the triatomic structure $(-\mathrm{C}=\mathrm{N}-\mathrm{N}-)$ [14]. The structural characteristics that make the hydrazone group a unique functional moiety is the presence of an imine carbon that is both nucleophilic and electrophilic, a nucleophilic imine and amino type nitrogen, and acidic hydrogen attached to the amino nitrogen [15]. In comparison with simple hydrazones, aroylhydrazones containing heterocyclic rings possess additional donor sites which present a more extensive scope of properties for these molecules [16]. Pyridine-based hydrazones have drawn a lot of interest among heterocyclic aroylhydrazones because they are frequently employed in asymmetric catalysis and serve as a good ligand with a high degree of flexibility in coordination [17].

In the present study, a detailed characterization of the newly synthesised metal complexes has been performed by combining experimental and high-level theoretical calculations in order to understand the structure and properties to an electronic level [18]. The theoretical studies carried out provide all the indispensable information about the structure, bonding, electron 
distribution and reactivity of the metal complexes. Moreover, the study of the interactions between transition metal complexes and DNA offers the opportunity to explore systematically how factors like molecular shape and hydrogen bonding stabilize the test molecules on DNA. These minuscule molecules bind to DNA through a series of weak interactions, including pistacking interactions associated with intercalation of aromatic chromophore between base pairs, hydrogen bonding and van der waals interactions of functionalities bound along the DNA helical groove. The physicochemical properties of ligand and one of the complexes (5) were studied using CT DNA, and the results showed that the complex had a higher affinity for DNA binding than the ligand. The findings are expected to spur the development of a newer metal complex with DNA as its ultimate target.

In this work, five novel $\mathrm{Ni}$ (II) complexes derived from HFPB were synthesised and characterised using several physicochemical methods. In particular, DFT calculations were performed to validate the experimental results and to explore the structural properties in detail. Further, hirshfeld surface analysis was also carried out, as this provides an additional insight into weak intermolecular interactions influencing the packing of molecules in crystals. Notably in this work we could also develop a halogen bonding directed molecular assembly in one of the complexes as evident from its crystal structure.

\section{Experimental}

\subsection{General Remarks}

All starting materials were commercially available and were used without further purification. Elemental analyses of the aroylhydrazone and the complexes were performed using Vario EL III CHNS elemental analyzer. The magnetic susceptibility measurements of the complexes were carried out on a Vibrating Sample Magnetometer using $\mathrm{Hg}\left[\mathrm{Co}(\mathrm{SCN})_{4}\right]$ as a calibrant at the Sophisticated Analytical Instrument Facility, Indian Institute of Technology, Madras. Infrared spectra were recorded on Perkin Elmer Spectrum 100 model Spectrometer using $\mathrm{KBr}$ pellets. The electronic spectra were recorded on Thermo Scientific Evolution 220 UV-Visible Spectrophotometer in 200-900 nm range. TG-DTG analyses of the complexes were carried out in a Perkin Elmer Pyris Diamond TG/DTA analyzer under nitrogen at a heating rate of $10{ }^{\circ} \mathrm{C} \mathrm{min}-1$ in the $50-700{ }^{\circ} \mathrm{C}$ range at the Sophisticated Analytical Instrument Facility, Cochin University of Science and Technology, Kochi-22, Kerala, India.

Single crystal X-ray diffraction studies of complex 5 were carried out using Bruker SMART APEXII CCD diffractometer equipped with graphite monochromated Mo $\operatorname{K\alpha }(\lambda=0.71073 \AA)$ 
radiation at the Sophisticated Analytical Instrument Facility, Cochin University of Science and Technology, Kochi-22, Kerala, India.

\subsection{Synthesis of the aroylhydrazone and its $\mathrm{Ni}(\mathrm{II})$ chelates}

The aroylhydrazone of our interest $\quad N^{\prime}$-[(E)-(3-fluoropyridin-2-yl)methylidene $]$ benzohydrazide monohydrate $\left(\mathrm{HFPB} \cdot \mathrm{H}_{2} \mathrm{O}\right)$ was synthesized by adapting a previously reported procedure [19] via condensation between 3-flouropicolinaldehyde and the corresponding aroylhydrazide (Scheme 1). The synthesis and crystal structure of HFPB $\cdot \mathrm{H}_{2} \mathrm{O}$ have been published earlier [20]. To validate the utility of this methodology, the reaction was also performed with different stoichiometric ratios of the reactants.

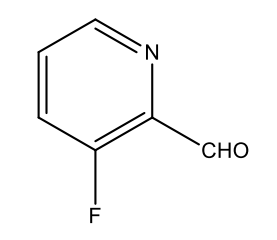

3-fluoropicolinaldehyde

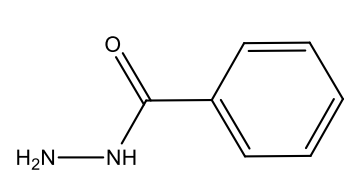

benzohydrazide

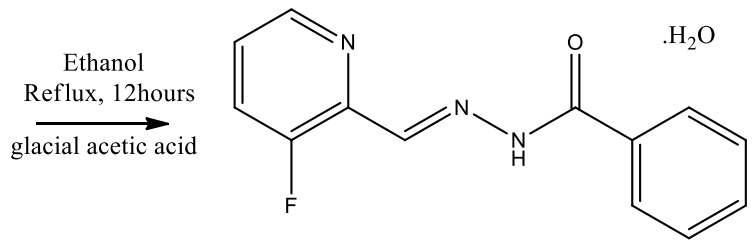

3-Fluoropyridine-2-carbaldehyde benzhydrazone monohydrate (HFPB. $\mathrm{H}_{2} \mathrm{O}$ )

Scheme 1. Synthesis of 3-Fluoropyridine-2-carbaldehyde benzhydrazone monohydrate $\left(\mathrm{HFPB} \cdot \mathrm{H}_{2} \mathrm{O}\right)$

\subsection{1 $\left[\mathrm{Ni}(\mathrm{FPB})\left(\mathrm{NO}_{3}\right)\right] \cdot 2 \mathrm{H}_{2} \mathrm{O}(1)$}

This complex has been prepared by mixing hot methanolic solution of $\mathrm{HFPB} \cdot \mathrm{H}_{2} \mathrm{O}(0.2612 \mathrm{~g}$, $1 \mathrm{mmol}$ ) with methanolic solution of nickel(II) nitrate hexahydrate $(0.2908,1 \mathrm{mmol})$ (Scheme 2 ). The resulting mixture was then refluxed for 5 hours. The solution was then cooled at room temperature and green color product obtained was filtered, washed with methanol followed by ether and dried over $\mathrm{P}_{4} \mathrm{O}_{10}$ in vacuo.

[Ni(FPB) $\left.\left(\mathrm{NO}_{3}\right)\right] \cdot 2 \mathrm{H}_{2} \mathrm{O}(1)$ : Yield: $65 \%, \lambda_{\mathrm{m}}(\mathrm{DMF}): 12 \mathrm{ohm}^{-1} \mathrm{~cm}^{2} \mathrm{~mol}^{-1}, \mu_{\text {eff }}($ B.M.): 2.87, Elemental Anal. Found (Calcd.) (\%): C: 39.68 (39.14); H: 3.71 (3.28); N: 14.53 (14.04).

\subsection{2 [Ni(HFPB $)($ FPB $)] C l(2)$}

A solution of HFPB $\cdot \mathrm{H}_{2} \mathrm{O}(0.2612 \mathrm{~g}, 1 \mathrm{mmol})$ in methanol was treated with a methanolic solution of nickel(II) chloride hexahydrate $(0.2377 \mathrm{~g}, 1 \mathrm{mmol})$. The resulting green color solution was then refluxed for 4 hours. The solution was cooled at room temperature and after slow evaporation, brown colored product separated out was filtered, washed with methanol followed by ether and dried over $\mathrm{P}_{4} \mathrm{O}_{10}$ in vacuo. 
[Ni(HFPB)(FPB)]Cl (2): Yield: 71\%, $\lambda_{\mathrm{m}}(\mathrm{DMF}): 87 \mathrm{ohm}^{-1} \mathrm{~cm}^{2} \mathrm{~mol}^{-1}, \mu_{\mathrm{eff}}$ (B.M.): 2.79, Elemental Anal. Found (Calcd.) (\%): C: 54.50 (53.88); H: 3.77 (3.30); N: 15.08 (14.50).

\subsection{3 $[\mathrm{Ni}(\mathrm{FPB})(\mathrm{OAc})(\mathrm{DMF})](3)$}

A solution of HFPB $\mathrm{H}_{2} \mathrm{O}(0.2612 \mathrm{~g}, 1 \mathrm{mmol})$ in methanol was treated with a methanolic solution of $\mathrm{Ni}(\mathrm{OAc})_{2} \cdot 4 \mathrm{H}_{2} \mathrm{O}(0.2480 \mathrm{~g}, 1 \mathrm{mmol})$. The resulting solution was then refluxed for about 4 hours. The precipitated complex was then recrystallized from DMF, brown colored product separated out was filtered, finally washed with ether and dried over $\mathrm{P}_{4} \mathrm{O}_{10}$ in vacuo.

[Ni(FPB)(OAc)(DMF)] (3): Yield: 68\%, $\lambda_{\mathrm{m}}(\mathrm{DMF}): 6 \mathrm{ohm}^{-1} \mathrm{~cm}^{2} \mathrm{~mol}^{-1}, \mu_{\text {eff }}($ B.M.): 2.69, Elemental Anal. Found (Calcd.) (\%): C: 50.49 (49.92); H: 4.83 (4.42); N: 13.33 (12.94).

\subsection{4 $\left[\mathrm{Ni}(\mathrm{FPB})\left(\mathrm{ClO}_{4}\right)\right] \cdot \mathrm{DMF}(4)$}

To a methanolic solution of HFPB $\cdot \mathrm{H}_{2} \mathrm{O}(0.2612 \mathrm{~g}, 1 \mathrm{mmol})$, nickel(II) perchlorate hexahydrate $(0.3650 \mathrm{~g}, 1 \mathrm{mmol})$ dissolved in methanol was added. The resulting solution was stirred and refluxed for about 5 hours. On slow evaporation at room temperature, green color needle shaped crystals were separated. The precipitated complex was then recrystallized from DMF, filtered, washed with methanol followed by ether and dried over $\mathrm{P}_{4} \mathrm{O}_{10}$ in vacuo.

[Ni(FPB) $\left.\left(\mathrm{ClO}_{4}\right)\right]$.DMF (4): Yield: 72\%, $\lambda_{\mathrm{m}}(\mathrm{DMF}): 5 \mathrm{ohm}^{-1} \mathrm{~cm}^{2} \mathrm{~mol}^{-1}, \mu_{\text {eff }}(\mathrm{B} . \mathrm{M}):$.2.92 , Elemental Anal. Found (Calcd.) (\%): C: 41.21 (40.59); H: 3.88 (3.41); N: 12.26 (11.83).

\subsection{5 [Ni(FPB $\left.)_{2}\right](5)$}

A methanolic solution of $\mathrm{Ni}(\mathrm{OAc})_{2} \cdot 4 \mathrm{H}_{2} \mathrm{O}(0.1240 \mathrm{~g}, 0.5 \mathrm{mmol})$ was treated with a solution of $\mathrm{HFPB} \cdot \mathrm{H}_{2} \mathrm{O}(0.2612 \mathrm{~g}, 1 \mathrm{mmol})$ in methanol. The resulting solution was then refluxed for 4 hours. The brown product formed immediately was filtered. The solution was cooled at room temperature and after slow evaporation, brown colored product separated out was filtered. It was then recrystallized from DMF solution, dark brown shining crystals separated were filtered, finally washed with ether and dried over $\mathrm{P}_{4} \mathrm{O}_{10}$ in vacuo.

[Ni(FPB $\left.)_{2}\right](5):$ Yield: $73 \%, \lambda_{\mathrm{m}}(\mathrm{DMF}): 11 \mathrm{ohm}^{-1} \mathrm{~cm}^{2} \mathrm{~mol}^{-1}, \mu_{\mathrm{eff}}$ (B.M.): 2.74, Elemental Anal. Found (Calcd.) (\%): C: 57.70 (57.49); H: 3.46 (3.34); N: 15.61 (15.47). 


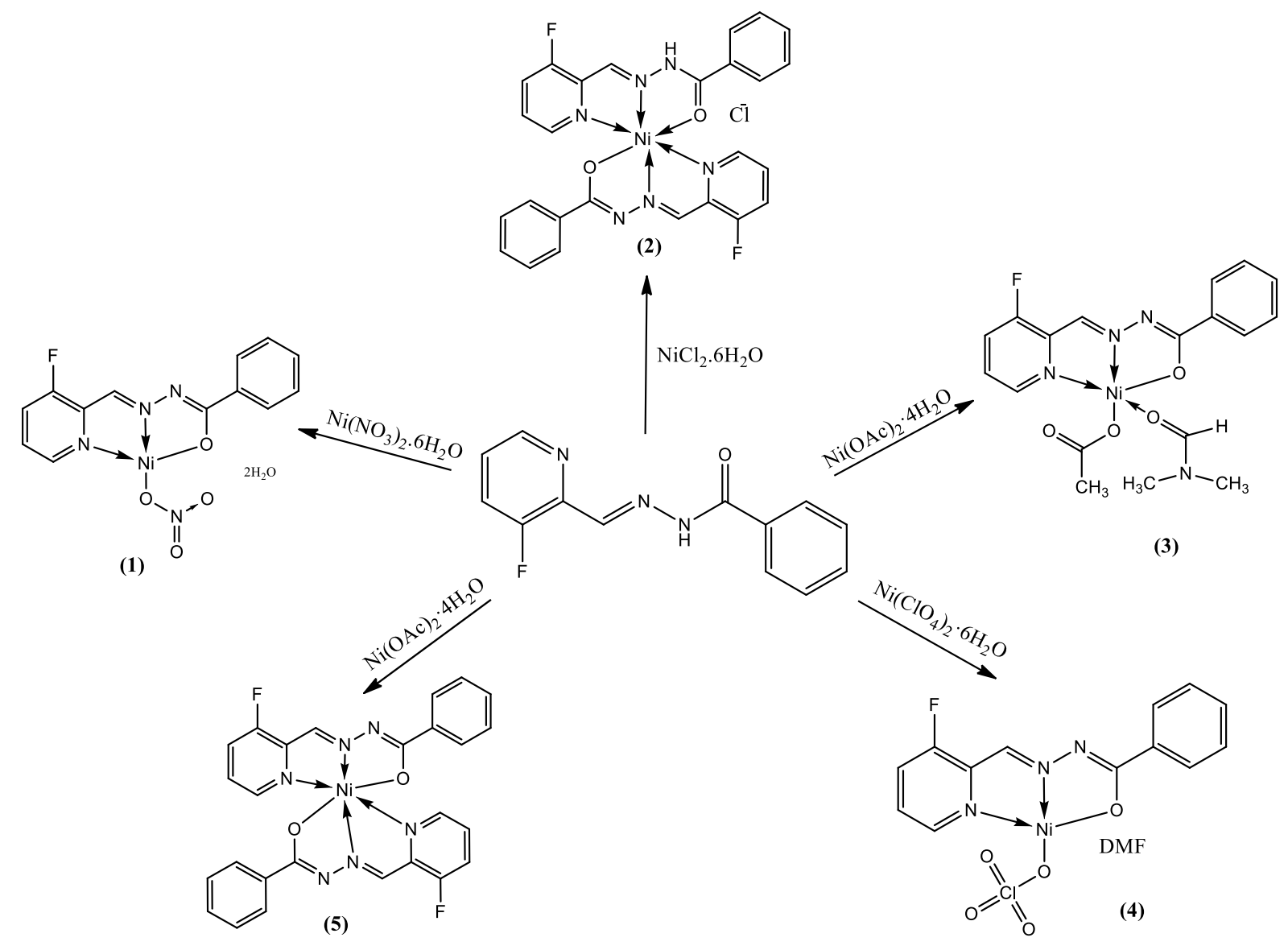

Scheme 2. Synthesis of complexes

\section{$2.3 X$-ray crystallography}

Single crystals of compound $\mathbf{5}$ of X-ray diffraction quality were grown from its DMF solution by slow evaporation at room temperature in air. A single crystal of suitable dimensions of the complex 5 was selected and mounted on a Bruker SMART APEXII CCD diffractometer with graphite-monochromated $\operatorname{MoK} \alpha(\lambda=0.71073 \AA)$ radiation at the Sophisticated Analytical Instruments Facility (SAIF), Cochin University of Science and Technology, Kochi-22, Kerala, India. The crystallographic data and structure refinement parameters are given in Table 4.3. Bruker SMART software was used for data acquisition and Bruker SAINT software for data integration [21]. Absorption corrections were carried out using SADABS based on Laue symmetry using equivalent reflections . The cell refinement was done using APEX2 and SAINT. The data was reduced using SAINT and XPREP. The structure was solved by direct methods using SHELXS97 and refined by full-matrix least-squares refinement on $\mathrm{F}^{2}$ using SHELXL2018/1 [22]. The molecular and crystal structures were plotted using DIAMOND version 3.2g [23]. 


\subsection{Hirshfeld surface analysis}

It is possible to get a clear picture of intermolecular interactions present in the molecule from Hirshfeld surface and 2D fingerprint analysis [24]. Crystal Explorer v 3.1 software package is used for the analysis. The electronic distribution results from the sum of isotopic atom electron densities are the concept behind HSs. Three functions, $d_{\text {norm }}$, shape index and curvedness are used for the mapping of HSs. $\mathrm{d}_{\text {norm }}$ is the normalized contact distance which indicates the ratio covering the distance of any surface point to the nearest interior $\left(\mathrm{d}_{\mathrm{i}}\right)$ and exterior $\left(\mathrm{d}_{\mathrm{e}}\right)$ atom and the van der Waals radii $\left(\mathrm{r}^{\mathrm{vdw}}\right)$ of the atoms. It is given by the expression

$$
\mathrm{d}_{\text {norm }}=\frac{\mathrm{di}-\mathrm{ri}^{\mathrm{vdW}}}{\mathrm{ri}^{\mathrm{vdW}}}+\frac{\mathrm{de}-\mathrm{re}^{\mathrm{vdW}}}{\mathrm{re}^{\mathrm{vdW}}}
$$

With a range of value of -0.1986-1.3914 $\AA$ of $\mathrm{d}_{\text {norm }}$ function, -1.0-1.0 $\AA$ of shape index and 4.0-4.0 Á of curvedness, HSs were mapped. Using $\mathrm{d}_{\text {norm }}$ function, we can analyse the deviation of intermolecular interactions visually. A red color indicates interactions are shorter than $\mathrm{r}^{\mathrm{vdw}}$, a blue color (positive $\mathrm{d}_{\text {norm }}$ value) indicates interactions are longer than $\mathrm{r}^{\mathrm{vdw}}$ and interactions equal to $\mathrm{r}^{\mathrm{vdw}}$ (zero $\mathrm{d}_{\text {norm }}$ value) are white in colour. A quantified information is obtained from the $2 \mathrm{D}$ fingerprint plots using $\left(\mathrm{d}_{\mathrm{e}}, \mathrm{d}_{\mathrm{i}}\right)$ pairs. In the FPs, we can observe complementary regions with one molecule as donor and other with acceptor.

\subsection{Computational aspects}

All DFT/B3LYP [25,26] computations of HFPB precursor and five Ni(II) complexes were performed by using the G09W package [27] at LANL2DZ [28] for heavy atoms and 6-31++g** $[29,30]$ for the remaining atoms. In theoretical chemistry, the Koopmans' Theorem [31] is the first important step in the prediction of the chemical reactivity behavior through using the FMO energies to calculate the ionization energy " $P$ " and electron affinities " $A$ " as follow

$$
\begin{aligned}
& I=-\mathrm{E}_{\text {HOMO }} \\
& A=-\mathrm{E}_{\text {LUMO }}
\end{aligned}
$$

These values are also used to calculate the QCP (quantum chemical parameters) [32-34] defined as

$$
\begin{aligned}
& \chi=-\frac{I+A}{2} \\
& \eta=\frac{I-A}{2} \\
& \omega=\frac{\mu^{2}}{2 \eta}
\end{aligned}
$$




$$
\Delta N_{\max }=\frac{I+A}{2(I-A)}
$$

Here, the terms as follows: $\chi \rightarrow$ "electronic chemical potential", $\eta \rightarrow$ "global hardness", $\omega \rightarrow$ "electrophilicity", and $\Delta \mathrm{N}_{\max } \rightarrow$ "maximum charge transfer capability".

Also, the $\omega$ - "the electrodonating power" and $\omega^{+}$"the electroaccepting power" values [35] are introduced depending on the FMO energies as follows

$$
\begin{aligned}
& \omega^{+} \approx(I+3 A)^{2} /(16(I-A)) \\
& \omega^{-} \approx(3 I+A)^{2} /(16(I-A))
\end{aligned}
$$

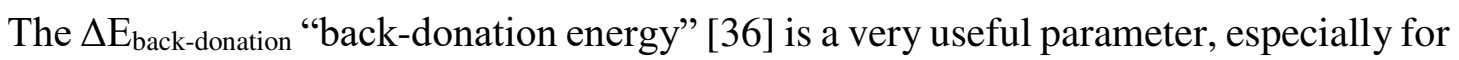
the aromatic systems, which can be calculated by the following equation.

$$
\Delta \varepsilon_{\text {back-donation }}=-\frac{\eta}{4}
$$

$\mathrm{E}^{(2)}$ "lowering of the second-order perturbative energy" obtained from the NBO "Natural Bond Orbital" analysis [37,38] is defined as

$$
E^{(2)}=\Delta E_{i j}=q i \frac{(F i j)^{2}}{(\varepsilon j-\varepsilon i)}
$$

Here, the terms are defined $\quad q_{i} \rightarrow$ "bonding orbital occupancy", $\varepsilon i$ and $\varepsilon j \rightarrow$ "bonding and antibonding orbital energies" (diagonal elements), and Fij $\rightarrow$ the off-diagonal NBO Fock matrix element.

GausView 6.0.16 [39] package was used to visualization of the FMO amplitudes.

\subsection{DNA binding studies}

The interaction of DNA with Ni(II) complex of octahedral geometry (5) is studied as it is found to be a potential candidate due to its geometry and steady state emission. The binding efficiency of complex was monitored using absorption and fluorometric studies.

\subsubsection{Electronic absorption titration}

The intrinsic binding constant $\left(\mathrm{K}_{\mathrm{b}}\right)$ of metal complex 5 with calf thymus DNA (CT- DNA) was determined using UV-Visible absorption spectroscopy (ligands are precipitating with buffer hence results for ligands are not shown). The stock CT - DNA solution was prepared by dissolving the DNA in Tris buffer $(\mathrm{NaCl} 50 \mathrm{mM}$, Tris - $\mathrm{HCl} 5 \mathrm{mM})$ at $\mathrm{pH}$ in the range of 7.27.4. The protein free state of CT-DNA was confirmed by measuring absorbance ratio at 260 and $280 \mathrm{~nm}$ (A260/A280) having greater than 1.8. The concentration of nucleic acid solution was determined by taking the UV absorbance at $260 \mathrm{~nm}$ after diluting to 1: 100 ratio and considering the molar extinction coefficient $6600 \mathrm{M}^{-1}$. The stock solution of the metal complex was prepared by dissolving stoichiometric amount of metal complex (5) in 5\% DMSO. DNA 
titration was done by successive addition of DNA solution to the metal complex $(25 \mu \mathrm{M})$ at room temperature. The spectra were recorded for 5-50 $\mu \mathrm{M}$ addition of DNA after 2 minutes of equilibration allowing the metal complex to interact with base pairs of CT- DNA. The binding efficiency in terms of $\mathrm{K}_{\mathrm{b}}$ was evaluated from the plot of [DNA] vs DNA]/( $\left.\varepsilon_{\mathrm{a}}-\varepsilon_{\mathrm{f}}\right)$ using the following equation

$$
[\mathrm{DNA}] /\left(\varepsilon_{\mathrm{a}}-\varepsilon_{\mathrm{f}}\right)=[\mathrm{DNA}] /\left(\varepsilon_{\mathrm{b}}-\varepsilon_{\mathrm{f}}\right)+1 /\left[\mathrm{K}_{\mathrm{b}}\left(\varepsilon_{\mathrm{b}}-\varepsilon_{\mathrm{f}}\right)\right]
$$

where, $[\mathrm{DNA}]=$ concentration of DNA

$\varepsilon_{A}=$ Apparent molar extinction coefficient of the compound

$\varepsilon_{B}=$ molar extinction coefficient of the compound in bounded form

$\varepsilon_{F}=$ molar extinction coefficient of the free compound

On plotting between [DNA] $/\left(\varepsilon_{\mathrm{a}}-\varepsilon \mathrm{f}\right)$ versus [DNA] gave a slope and intercept equal to $1 /\left(\varepsilon_{\mathrm{a}}-\right.$ $\left.\varepsilon_{\mathrm{f}}\right)$ and $\left(1 / \mathrm{K}_{\mathrm{b}}\right)\left(1 /\left(\varepsilon_{\mathrm{b}}-\varepsilon_{\mathrm{f}}\right)\right)$, respectively and the $\mathrm{K}_{\mathrm{b}}$ value for the complex was obtained as the ratio of the slope to the intercept. The percentage of hyperchromicity for the complex was obtained from $\left(\varepsilon_{\mathrm{a}}-\varepsilon_{\mathrm{f}}\right) / \varepsilon_{\mathrm{f}} \times 100$. The stock CT-DNA solution prepared in tris buffer $(\mathrm{NaCl} 50$ $\mathrm{mM}$, Tris - $\mathrm{HCl} 5 \mathrm{mM}$ ) at $\mathrm{pH}$ 7.2-7.4 gave an absorbance ratio (A260/A280) greater than 1.8, exposing CT DNA is sufficiently free from protein contamination.

\subsubsection{Fluorescent spectroscopic studies}

To examine whether the complex can displace ethidium bromide (EB) from its CT-DNA-EB complex, the fluorescent titration was carried out. The EB solution was made from Tris $\mathrm{HCl} / \mathrm{NaCl}$ buffer, maintaining the $\mathrm{pH}$ at 7.2. The emission intensity of the EB- CT DNA complex was recorded at $596 \mathrm{~nm}$. The complex solution was incrementally added $(0-50 \mu \mathrm{M})$ to DNA-EB system and the change in intensity was recorded. The excitation and emission slit widths were set to $5 \mathrm{~nm}$. The response time $(0.04 \mathrm{~s})$, excitation voltage $(700 \mathrm{~V})$ and scan rate $(1500 \mathrm{~nm} / \mathrm{min})$ kept constant for each data set. The appropriate blank solution corresponding to the buffer solution was subtracted to correct background of fluorescence. To eliminate the possible inner filter effect arising from UV-Visible absorption of CT-DNA, the fluorescence data were corrected before analysis of the binding and quenching data. A quartz cell of onecentimetre diameter was used throughout the experiments and all the measurements were performed at room temperature. The fluorescence spectra of the test compound were recorded by using the excitation wavelength $241 \mathrm{~nm}$ for complex 5 while the emission wavelength was $372 \mathrm{~nm}$. In the ethidium bromide (EB) displacement method, to a mixture of $10 \mu \mathrm{L}$ of the EB in tris-buffer solution $(50 \mu \mathrm{M})$ and $10 \mu \mathrm{L}$ of DNA solution (10 $\mu \mathrm{L}$ at saturated binding level), the compound was added, and the mixture was well mixed at room temperature for $5 \mathrm{~min}$ before 
measurements. The spectra of EB bound to DNA were obtained at an excitation wavelength of $241 \mathrm{~nm}$ and an emission wavelength of $372 \mathrm{~nm}$. The observed quenching was analysed according to the classical Stern-Volmer equation (Equation 3).

$$
\frac{\mathrm{F}_{0}}{\mathrm{~F}}=1+\mathrm{k}_{\mathrm{q}} \tau_{0}[\mathrm{Q}]=1+\mathrm{K}_{\mathrm{SV}}[\mathrm{Q}]
$$

where $F_{0}$ and $F$ are fluorescence intensities in the absence and presence of quencher (test compound), respectively; $\mathrm{K}_{\mathrm{SV}}$ is linear Stern-Volmer quenching constant; [Q] is the concentration of quencher and $\tau_{\mathrm{o}}$ is the average fluorescence lifetime of the biomolecule in absence of the quencher.

\subsection{Docking Studies}

Docking Server system was used in carrying out all the docking calculations [40]. Geometry optimization of the complexes was carried out using the MMFF94 method. The Gasteiger charge calculation method was applied to the complexes. A pH which is equal to 7.0 is preferred in all calculations. Grid maps $90 \times 90 \times 90 \hat{A}(x, y$ and z) and Lamarckian genetic algorithm (LGA) methods were used in the placement calculations [41]. At the time of insertion, the population size was set to 150. A translation step of $0.2 \AA$ and a $5 \AA$ quaternion and torsion steps were applied during the search for the appropriate region of the target protein of the molecules studied.

\section{Results and Discussion}

\subsection{Synthesis, molar conductivity, and magnetic susceptibility measurements}

The complexes were obtained from direct reaction between the metal salts and the ligand using methanol as solvent. Elemental analyses suggested a deprotonated iminolate form of the ligand is present in most of the complexes, however in few cases ligand is binding to the metal center in the neutral amido form, with the anions of the metal salt satisfying the $\mathrm{Ni}$ (II) valency. The complexes prepared were green or dark brown in color and are found to be readily soluble in solvents like DMF and DMSO but less soluble in solvents like ethanol, methanol and chloroform. All the isolated complexes were quite stable and could be stored for several weeks without any appreciable change. X-ray quality single crystals of one of the complexes, $\left[\mathrm{Ni}(\mathrm{FPB})_{2}\right](5)$ were obtained by the recrystallization of the compound from its DMF solution. Molar conductivity of the complexes was measured in the $10^{-3} \mathrm{M}$ DMF solution and were found to be non-electrolytic in nature except complex 2 which is a 1:1 electrolyte [42]. The molar conductivity value of this complex is found to be in the range $87 \mathrm{ohm}^{-1} \mathrm{~cm}^{2} \mathrm{~mol}^{-1}$. 
The magnetic properties of Ni complexes provide valuable information for distinguishing their geometry. All the nickel complexes were found to be paramagnetic which excludes the possibility of a square planar configuration. At room temperature the effective magnetic moments ( $\mu_{\text {eff }}$ ) of complexes $\mathbf{2}, \mathbf{3}$ and $\mathbf{5}$ are found to be in the range 2.6-2.8 B.M., consistent with octahedral geometry for these complexes [43]. In regular octahedral complexes of $\mathrm{Ni}(\mathrm{II})$, consideration of spin-orbit coupling and contribution from the ${ }^{3} A_{2 \mathrm{~g}}$ and the next higher ${ }^{3} T_{2 \mathrm{~g}}$ states give a higher magnetic moment than the spin-only moment of 2.83 B.M. For complexes 1 and 4, magnetic moments were found to be in the range 2.8-3.2 B.M. which are slightly higher than their spin only values, suggesting some orbital contributions in this case and are similar to that of other reported tetrahedral $\mathrm{Ni}(\mathrm{II})$ complexes [44].

\subsection{Spectral characterization}

\subsubsection{Infrared spectroscopy}

The IR spectrum of the hydrazone and their $\mathrm{Ni}$ (II) complexes were recorded in the solid state as $\mathrm{KBr}$ discs. The characteristic IR bands for the free ligand when compared with metal complexes provide meaningful information regarding the bonding sites of the ligands. The selected IR bands of the hydrazones and complexes are represented in Table 1.

Table 1. The important IR frequencies $\left(\mathrm{cm}^{-1}\right)$ of hydrazones and their Ni(II) complexes

\begin{tabular}{lcccc}
\hline \multicolumn{1}{c}{ Compound } & $\mathbf{v}(\mathbf{N}-\mathbf{H})$ & $\mathbf{v}(\mathbf{C}=\mathbf{O}) / \mathbf{v}(\mathbf{C}-\mathbf{O})$ & $\mathbf{v}(\mathbf{C}=\mathbf{N})$ & $\mathbf{v}(\mathbf{C}=\mathbf{N})^{\mathbf{a}}$ \\
\hline $\mathrm{HFPB} \cdot \mathrm{H}_{2} \mathrm{O}$ & 3059 & 1683 & 1597 & -- \\
{$\left[\mathrm{Ni}(\mathrm{FPB})\left(\mathrm{NO}_{3}\right)\right] \cdot 2 \mathrm{H}_{2} \mathrm{O}(\mathbf{1})$} & -- & 1353 & 1570 & 1590 \\
{$[\mathrm{Ni}(\mathrm{HFPB})(\mathrm{FPB})] \mathrm{Cl}(\mathbf{2})$} & 3020 & 1647,1368 & 1550 & 1560 \\
{$[\mathrm{Ni}(\mathrm{FPB})(\mathrm{OAc})(\mathrm{DMF})](\mathbf{3})$} & -- & 1328 & 1547 & 1570 \\
{$\left[\mathrm{Ni}(\mathrm{FPB})\left(\mathrm{ClO}_{4}\right)\right] \cdot \mathrm{DMF}(\mathbf{4})$} & & 1341 & 1555 & 1587 \\
{$\left[\mathrm{Ni}(\mathrm{FPB})_{2}\right](\mathbf{5})$} & & 1327 & 1567 & 1590 \\
\hline
\end{tabular}

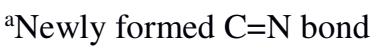

The IR spectrum of the aroylhydrazone exhibit two bands in the range 3058 and $1682 \mathrm{~cm}^{-1}$ due to the $v(\mathrm{NH})$ and $v(\mathrm{C}=\mathrm{O})$, respectively, and these bands are absent in the case of complexes. This indicates that the ligand coordinates to the metal in an iminolate form. The aroylhydrazone has a band at $1597 \mathrm{~cm}^{-1}$ due to azomethine group. This suffers a shift to lower wave number in the complexes. This indicates the coordination of azomethine nitrogen to $\mathrm{Ni}(\mathrm{II})$ in the complexes [14]. 
According to Stefov et al., the broad band above $3200 \mathrm{~cm}^{-1}$ in complex 1 indicates the presence of lattice water and a new medium intensity band in the region $1353 \mathrm{~cm}^{-1}$ may be assigned to $v(\mathrm{C}-\mathrm{O})$ stretching vibration [45]. The IR spectrum of $\left[\mathrm{Ni}(\mathrm{FPB})\left(\mathrm{NO}_{3}\right)\right] \cdot 2 \mathrm{H}_{2} \mathrm{O}$ (1) (Fig. S1) exhibits two bands at 1448 and $1325 \mathrm{~cm}^{-1}$ corresponding to $\mathrm{N}=\mathrm{O}$ stretching vibrations of the nitrate ion. The separation of these bands by $120 \mathrm{~cm}^{-1}$ indicates the unidentate nature of the nitrate ion in the complex [43]. A positive shift corresponding to out-of-plane bending vibrations of the free ligand to higher frequencies in the complexes is confirmative of pyridine nitrogen coordination to the metal center. The IR data of $[\mathrm{Ni}(\mathrm{HFPB})(\mathrm{FPB})] \mathrm{Cl}$ (2) (Fig. S2) indicate that one aroylhydrazone is bound as a uni-negative anion via the pyridine nitrogen, azomethine nitrogen and iminolate oxygen. Moreover, the spectrum of compound 2 reveals a broad band around $3020 \mathrm{~cm}^{-1}$ corresponding to $\mathrm{N}-\mathrm{H}$ vibration. This explains the fact that one of the ligands is not deprotonated. The elemental analyses suggested the presence of chloride ion, but the conductivity measurements suggested complex 2 as a 1:1 electrolyte indicating the fact that one of the ligands is deprotonated and coordinating to the metal ion in the anionic form. The appearance of a new band at $1560 \mathrm{~cm}^{-1}$ due to newly formed $v(\mathrm{C}=\mathrm{N})$ supports the above observation. The complex 3 displays bands at 1570-1600 and 1415-1425 cm-1 (Fig. S3) regions due to the asymmetric and symmetric modes of vibration characteristic of acetate group, respectively. The frequency difference $\Delta v$ of acetate group is found at $\sim 150 \mathrm{~cm}^{-1}$ which is consistent with the bidentate nature of the acetate group [46]. In complex 4 (Fig. S4), the band at $1597 \mathrm{~cm}^{-1}$ assignable to $v(\mathrm{C}=\mathrm{N})$ in the free ligand was shifted to lower values indicating its participation in the chelation with $\pi$-electron delocalization. The perchlorate assignments in complex 4 were made by comparison to known values. Although regarded as weakly coordinating anion, perchlorate is known to coordinate under special conditions. Such interactions normally manifest themselves by splitting of the antisymmetric $(\mathrm{Cl}-\mathrm{O})$ stretching mode due to a reduced symmetry of the coordinated species. The absorption bands occurring in the IR spectrum of the complex 4 (Fig. S4) at 1095 and $649 \mathrm{~cm}^{-1}$ are assignable to $v_{3}\left(\mathrm{ClO}_{4}\right)$ and $v_{4}\left(\mathrm{ClO}_{4}\right)$ respectively [47]. Both show considerable splitting due to a reduced symmetry of the perchlorate species suggesting some interaction of perchlorate anion $\mathrm{ClO}_{4}{ }^{-}$with the metal. In complex 5 (Fig. S5), the ligand coordinates the metal center with nitrogen atoms from the pyridine and imino moieties and one oxygen atom coming from its iminolic counterpart. 


\subsubsection{Electronic spectroscopy}

The electronic spectral assignments of the complexes in DMF solutions are summarized in Table 2 and shown in Fig. 1. The absorption spectrum exhibits a charge transfer transition (CT) at 22000-29500 $\mathrm{cm}^{-1}$ region which may be assigned to the ligand-to-metal charge transfer from the coordinated unsaturated ligand to the metal ion. The absorption bands due to $n \rightarrow \pi^{*}$ and $\pi \rightarrow \pi^{*}$ transitions of free hydrazone suffered considerable shift upon complexation and the bands at $\sim 36100 \mathrm{~cm}^{-1}$ can be assigned to shifted intraligand transitions. This is due to the weakening of the $\mathrm{C}=\mathrm{O}$ bond and the extension of conjugation upon complexation [48].

Table 2 Electronic spectral assignments $\left(\mathrm{cm}^{-1}\right)$ of $\mathrm{Ni}(\mathrm{II})$ complexes

\begin{tabular}{lcc}
\hline \multicolumn{1}{c}{ Compound } & $\mathbf{n} \rightarrow \boldsymbol{\pi} * \boldsymbol{\pi} \rightarrow \boldsymbol{\pi}^{*}$ & LMCT \\
\hline$\left[\mathrm{Ni}(\mathrm{FPB})\left(\mathrm{NO}_{3}\right)\right] \cdot 2 \mathrm{H}_{2} \mathrm{O}(\mathbf{1})$ & 34800 & 24610 \\
{$[\mathrm{Ni}(\mathrm{HFPB})(\mathrm{FPB})] \mathrm{Cl}(\mathbf{2})$} & 34380 & $24840,23850(\mathrm{sh})$ \\
{$[\mathrm{Ni}(\mathrm{FPB})(\mathrm{OAc})(\mathrm{DMF})](\mathbf{3})$} & 34520 & 24800,23940 \\
{$\left[\mathrm{Ni}(\mathrm{FPB})\left(\mathrm{ClO}_{4}\right)\right] \cdot \mathrm{DMF}(\mathbf{4})$} & 34620 & 24800 \\
{$\left[\mathrm{Ni}(\mathrm{FPB})_{2}\right](\mathbf{5})$} & 34660 & 24800,23800 \\
\hline
\end{tabular}

The electronic spectra of $\mathrm{Ni}$ (II) complexes of regular $\mathrm{O}_{\mathrm{h}}$ symmetry have the following assignments for $d-d$ bands: ${ }^{3} T_{2 \mathrm{~g}}(\mathrm{~F}) \leftarrow{ }^{3} A_{2 \mathrm{~g}}(\mathrm{~F})\left(v_{1}\right),{ }^{3} T_{1 \mathrm{~g}}(\mathrm{~F}) \leftarrow{ }^{3} A_{2 \mathrm{~g}}(\mathrm{~F})\left(v_{2}\right)$ and ${ }^{3} T_{1 \mathrm{~g}}(\mathrm{P}) \leftarrow{ }^{3} A_{2 \mathrm{~g}}(\mathrm{~F})\left(v_{3}\right)[43,47]$, but unfortunately these $d-d$ bands are masked by the stronger CT absorption bands in these complexes and hence we did not observe seperate $d-d$ bands for such transitions. In Ni(II) complexes with tetrahedral stereochemistry, three transitions are expected ie. ${ }^{3} T_{2}(\mathrm{~F}) \leftarrow{ }^{3} T_{1}(\mathrm{~F}),{ }^{3} A_{2}(\mathrm{~F}) \leftarrow{ }^{3} T_{1}(\mathrm{~F})$, ${ }^{3} T_{1}(\mathrm{P}) \longleftarrow{ }^{3} T_{1}(\mathrm{~F})$; however we could not locate any of these bands, probably hidden under highintensity charge transfer bands [43]. The electronic spectra of the complexes in DMF solution are not well resolved owing to very intense charge transfer bands extending into visible portion of spectra. 


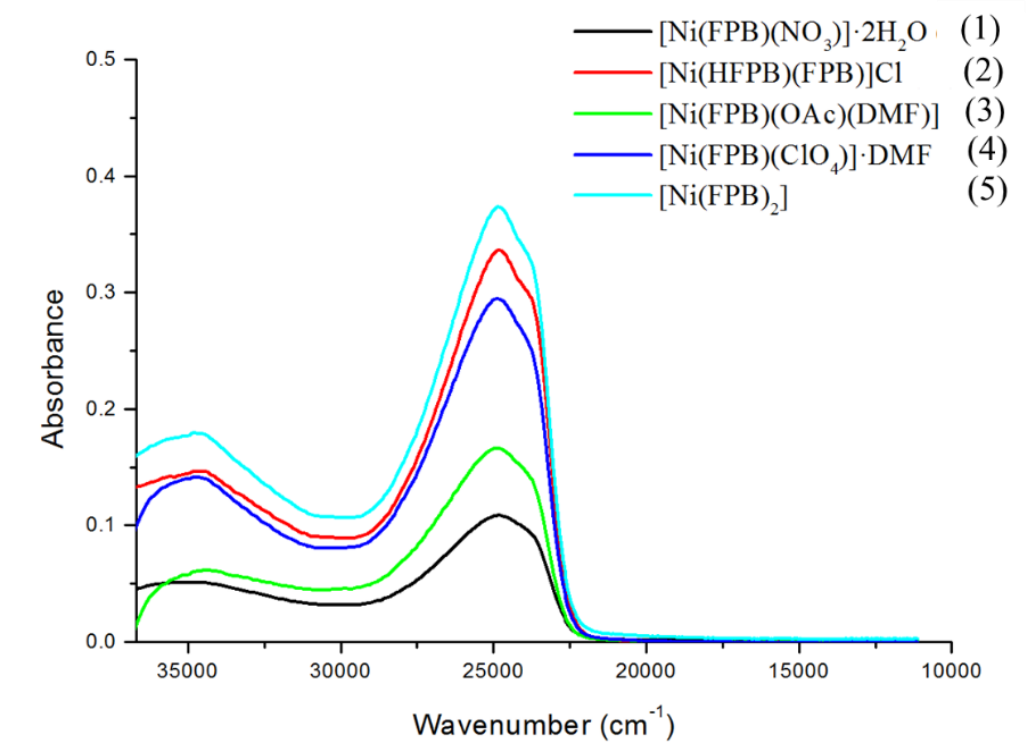

Fig. 1 Electronic spectra of nickel(II) complexes.

\subsection{Thermogravimetric analyses}

Thermogravimetric analysis is generally carried out to determine the thermal stability of the complexes. TG-DTG curve for the complex $\left[\mathrm{Ni}(\mathrm{FPB})\left(\mathrm{NO}_{3}\right)\right] \cdot 2 \mathrm{H}_{2} \mathrm{O}(\mathbf{1})$ (Fig. 2) shows a three step weight loss. At $150-230{ }^{\circ} \mathrm{C}$, a weight loss of $25.93 \%$ (Calcd. $24.57 \%$ ) occurs due to loss of two lattice water and nitrate ion. The weight loss of $36.105 \%$ (Calcd. $36.25 \%$ ) at $410{ }^{\circ} \mathrm{C}$ is due to loss of $\mathrm{C}_{6} \mathrm{H}_{4} \mathrm{FN}$ fragment of the aroylhydrazone moiety. After $410{ }^{\circ} \mathrm{C}$, compound decomposes continuously and yields different ratios of metal and metal oxide (NiO) as final product.

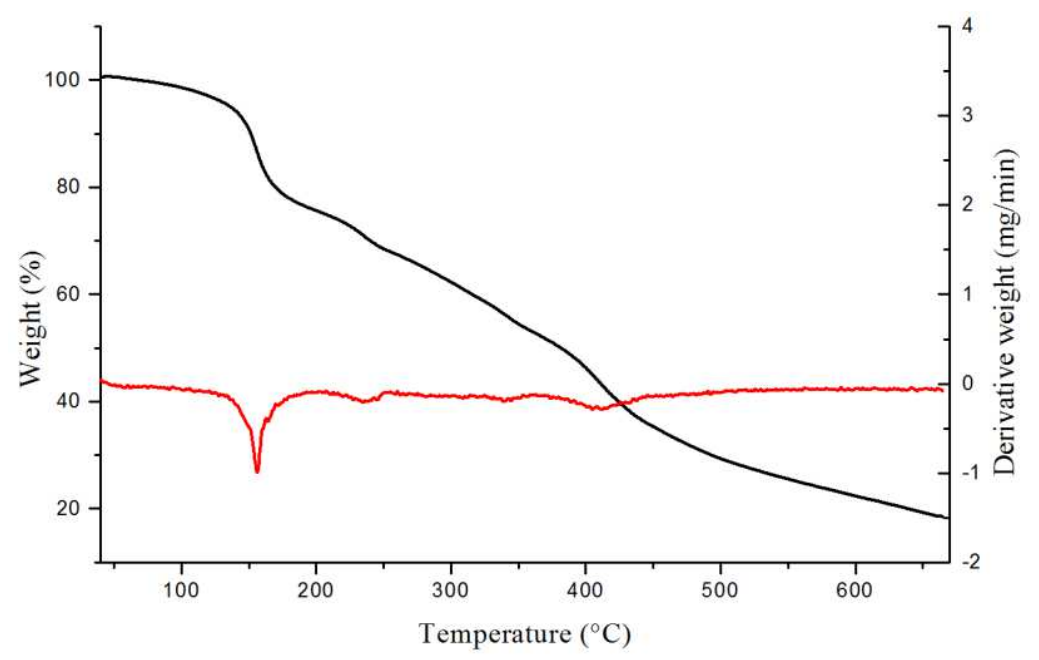

Fig. 2 Thermogram of $\left[\mathrm{Ni}(\mathrm{FPB})\left(\mathrm{NO}_{3}\right)\right] \cdot 2 \mathrm{H}_{2} \mathrm{O}(\mathbf{1})$. 


\subsection{Crystal structure description}

Dark brown crystals of complex $\left[\mathrm{Ni}(\mathrm{FPB})_{2}\right](5)$ suitable for $\mathrm{X}$-ray analysis were grown by recrystallization of the compound from dimethylformamide in a week time. Crystal data and structural refinement for the complex $\mathbf{5}$ are tabulated in the Table 3.

Table. 3 Crystal data and structure refinement parameters for $\left[\mathrm{Ni}(\mathrm{FPB})_{2}\right](\mathbf{5})$

\begin{tabular}{|c|c|}
\hline Parameters & {$\left[\mathrm{Ni}(\mathrm{FPB})_{2}\right](5)$} \\
\hline Empirical formula & $\mathrm{C}_{26} \mathrm{H}_{18} \mathrm{~F}_{2} \mathrm{~N}_{6} \mathrm{O}_{2} \mathrm{Ni}$ \\
\hline Formula weight & 543.15 \\
\hline Temperature & 293(2) K \\
\hline Wavelength & $0.71073 \AA$ \\
\hline Crystal system & Monoclinic \\
\hline Space group & $P 2{ }_{1} / \mathrm{c}$ \\
\hline \multicolumn{2}{|l|}{ Unit cell dimensions } \\
\hline & $\mathrm{a}=11.8775(8) \AA$ \\
\hline & $\mathrm{b}=8.6363(6) \AA$ \\
\hline & $\mathrm{c}=22.8725(17) \AA \quad \gamma=90^{\circ}$ \\
\hline Volume $\left(\AA^{3}\right)$ & $2346.2(3)$ \\
\hline $\mathrm{Z}$ & 4 \\
\hline Density (calculated) $\mathrm{mgm}^{-3}$ & 1.538 \\
\hline Absorption coefficient $\left(\mathrm{mm}^{-1}\right)$ & 0.881 \\
\hline $\mathrm{F}(000)$ & 1112 \\
\hline Crystal size & $0.30 \times 0.25 \times 0.20 \mathrm{~mm}^{3}$ \\
\hline$\theta$ range for data collection & 2.92 to $28.00^{\circ}$ \\
\hline Limiting indices & $-15 \leq \mathrm{h} \leq 15,-7 \leq \mathrm{k} \leq 11,-30 \leq \mathrm{l} \leq 30$ \\
\hline Reflections collected / unique & $16698 / 5673[\mathrm{R}(\mathrm{int})=0.0340]$ \\
\hline Completeness to $\theta$ & $28.00 \quad 99.6 \%$ \\
\hline Absorption correction & Semi-empirical from equivalents \\
\hline Max. and min. transmission & 0.825 and 0.755 \\
\hline Refinement method & Full-matrix least-squares on $\mathrm{F}^{2}$ \\
\hline Data / restraints / parameters & $5651 / 0 / 334$ \\
\hline Goodness-of-fit on $\mathrm{F}^{2}$ & 0.993 \\
\hline Final $\mathrm{R}$ indices $[\mathrm{I}>2 \sigma(\mathrm{I})]$ & $\mathrm{R}_{1}=0.0441, \mathrm{wR}_{2}=0.0981$ \\
\hline $\mathrm{R}$ indices (all data) & $\mathrm{R}_{1}=0.0681, \mathrm{wR}_{2}=0.1107$ \\
\hline Largest diff. peak and hole & 0.325 and -0.309 e. $\mathrm{A}^{-3}$ \\
\hline
\end{tabular}


A perspective view on the molecular structure of compound $\mathbf{5}$ along with atom numbering scheme is presented in Fig. 3 and selected bond lengths and bond angles are summarized in Table 4. The complex 5 crystallized in the monoclinic system with the space group $P 2_{1} / \mathrm{c}$.

Table. 4 Selected bond lengths and bond angles for $\left[\mathrm{Ni}(\mathrm{FPB})_{2}\right](\mathbf{5})$

\begin{tabular}{|c|c|c|c|c|}
\hline \multicolumn{3}{|c|}{ Bond lengths (Å) } & \multirow{2}{*}{\multicolumn{2}{|c|}{ Bond angles $\left({ }^{\circ}\right)$}} \\
\hline & $\mathbf{H F P B} \cdot \mathrm{H}_{2} \mathrm{O}$ & {$\left[\mathrm{Ni}(\mathrm{FPB})_{2}\right](5)$} & & \\
\hline $\mathrm{C}(6)-\mathrm{N}(2)$ & $1.2721(18)$ & $1.283(3)$ & $\mathrm{N}(5)-\mathrm{Ni}(1)-\mathrm{N}(2)$ & $177.27(9)$ \\
\hline $\mathrm{C}(19)-\mathrm{N}(5)$ & & $1.283(3)$ & $\mathrm{O}(2)-\mathrm{Ni}(1)-\mathrm{N}(4)$ & $154.50(8)$ \\
\hline $\mathrm{N}(2)-\mathrm{N}(3)$ & $1.3736(16)$ & $1.362(3)$ & $\mathrm{O}(1)-\mathrm{Ni}(1)-\mathrm{N}(1)$ & $154.46(8)$ \\
\hline $\mathrm{N}(5)-\mathrm{N}(6)$ & & $1.360(3)$ & $\mathrm{N}(5)-\mathrm{Ni}(1)-\mathrm{O}(1)$ & $106.55(8)$ \\
\hline $\mathrm{C}(7)-\mathrm{N}(3)$ & $1.3582(18)$ & $1.345(3)$ & $\mathrm{N}(2)-\mathrm{Ni}(1)-\mathrm{O}(1)$ & $103.67(8)$ \\
\hline$C(20)-N(6)$ & & $1.349(3)$ & $\mathrm{N}(2)-\mathrm{Ni}(1)-\mathrm{N}(4)$ & $101.82(8)$ \\
\hline $\mathrm{C}(7)-\mathrm{O}(1)$ & $1.2258(17)$ & $1.266(3)$ & $\mathrm{N}(5)-\mathrm{Ni}(1)-\mathrm{N}(1)$ & $98.99(9)$ \\
\hline $\mathrm{C}(20)-\mathrm{O}(2)$ & & $1.266(3)$ & $\mathrm{O}(2)-\mathrm{Ni}(1)-\mathrm{O}(1)$ & $94.06(8)$ \\
\hline $\mathrm{N}(1)-\mathrm{Ni}(1)$ & & $2.128(2)$ & $\mathrm{O}(1)-\mathrm{Ni}(1)-\mathrm{N}(4)$ & $92.57(8)$ \\
\hline $\mathrm{N}(2)-\mathrm{Ni}(1)$ & & $1.992(2)$ & $\mathrm{N}(1)-\mathrm{Ni}(1)-\mathrm{N}(4)$ & $92.41(8)$ \\
\hline $\mathrm{N}(4)-\mathrm{Ni}(1)$ & & $2.139(2)$ & $\mathrm{O}(2)-\mathrm{Ni}(1)-\mathrm{N}(1)$ & $92.14(8)$ \\
\hline $\mathrm{N}(5)-\mathrm{Ni}(1)$ & & $1.989(2)$ & $\mathrm{N}(2)-\mathrm{Ni}(1)-\mathrm{N}(1)$ & $78.28(9)$ \\
\hline $\mathrm{O}(1)-\mathrm{Ni}(1)$ & & $2.0925(19)$ & $\mathrm{N}(5)-\mathrm{Ni}(1)-\mathrm{N}(4)$ & $78.06(8)$ \\
\hline \multirow[t]{2}{*}{$\mathrm{O}(2)-\mathrm{Ni}(1)$} & & 2.0698(19) & $\mathrm{N}(5)-\mathrm{Ni}(1)-\mathrm{O}(2)$ & $76.45(8)$ \\
\hline & & & $\mathrm{N}(2)-\mathrm{Ni}(1)-\mathrm{O}(1)$ & $76.18(8)$ \\
\hline
\end{tabular}

The pre-eminence of the octahedral geometry in transition-metal six-coordination is assured by both steric and electronic factors. Nevertheless, substantial deformations from this polyhedral paradigm are well established in several transition metal complexes. In complex $\mathbf{5}$, $\mathrm{Ni}$ (II) is in a distorted octahedral $\mathrm{N}_{4} \mathrm{O}_{2}$ coordination environment, with each of the two ligands coordinating through the pyridine nitrogen, imino-hydrazone nitrogen and the deprotonated oxygen of the hydrazone moiety [49]. The four nitrogens and two oxygens of two hydrazone ligands surround the the $\mathrm{Ni}$ (II) ion in a meridional fashion. Bite angles also suggest coordination mode of the ligand is meridional and not facial. The unit cell of the compound $\mathbf{5}$ is formed by four molecular units $(Z=4)$ and no lattice water was found in the present crystal system. 


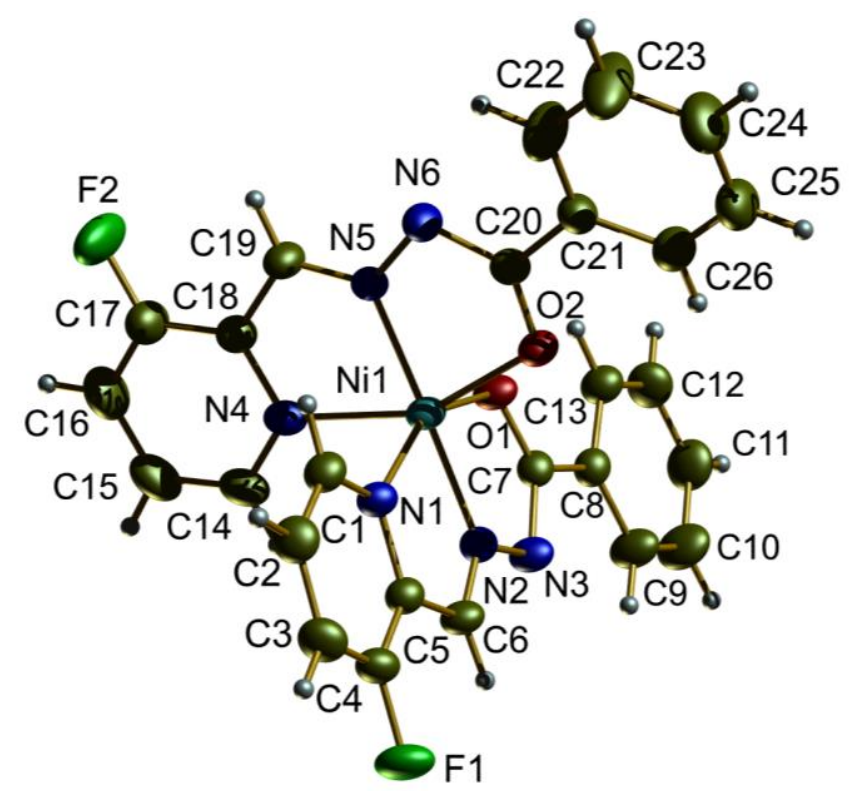

Fig. 3 Molecular structure of $\left[\mathrm{Ni}(\mathrm{FPB})_{2}\right](\mathbf{5})$.

The bond lengths $\mathrm{C}(6)-\mathrm{N}(2)$ of $1.283 \AA$ and $\mathrm{C}(7)-\mathrm{N}(3)$ of $1.345 \AA$ are comparable to that of other reported divalent transition metal complexes [50]. The cis angles, O1-Ni1-N4 $\left(92.57(8)^{\circ}\right)$ and $\mathrm{O} 2-\mathrm{Ni1}-\mathrm{N} 1\left(92.41(8)^{\circ}\right)$ and trans angles N5-Ni1-N2 $\left(177.27(9)^{\circ}\right), \mathrm{O} 2-\mathrm{Ni1}-$ $\mathrm{N} 4\left(154.5(8)^{\circ}\right)$ and $\mathrm{O} 1-\mathrm{Ni1}-\mathrm{N} 1\left(154.46(8)^{\circ}\right)$ clearly indicate a substantial departure from octahedral geometry. All the angles subtended at the Ni(II) ion by donor atoms show marked deviation from that expected for an ideal octahedral geometry. While O1, O2, N1 and N4 lie in the equatorial plane, N2 and N5 occupy the axial positions. The torsion angle of $178.7(2)^{\circ}$ observed for $\mathrm{C}(5)-\mathrm{C}(6)-\mathrm{N}(2)-\mathrm{N}(3)$ supports $E$ configuration with respect to $\mathrm{N}(2)=\mathrm{C}(6)$ bond (Table S6). The Ni-N(py), Ni-N(imine) and Ni-O bond lengths observed here are typically within the range of other reported octahedral $\mathrm{Ni}(\mathrm{II})$ complexes [52]. The $\mathrm{Ni}-\mathrm{N}(\mathrm{azo})$ bond lengths are less compared to $\mathrm{Ni}-\mathrm{N}($ py) indicating the strength of former than the latter. Coordination lengthens the hydrazone moiety's C(7)-O(1) bond distance by $0.0402 \AA$ and shortens the $\mathrm{C}(7)-\mathrm{N}(3)$ distance by $0.0132 \AA$, suggesting a deprotonation after iminolization.

No classical hydrogen bonds are seen in the crystal structure, and it is worth to point out that non-classical hydrogen bonds specifically $\mathrm{C}-\mathrm{H} \cdots \mathrm{N}, \mathrm{C}-\mathrm{H} \cdots \mathrm{O}$ and $\mathrm{C}-\mathrm{H} \cdots \mathrm{F}$ have been invoked as a key factor in the crystal packing forming a three-dimensional supramolecular structure (Fig. S7, S8, S9). Other non-covalent interactions like $\pi \cdots \pi, \mathrm{C}-\mathrm{H} \cdots \pi$ and halogen bonding (C$\mathrm{F} \cdots \pi$ ) interactions that play a determinant structure directing role stabilize the molecular packing in the supramolecular assembly. 


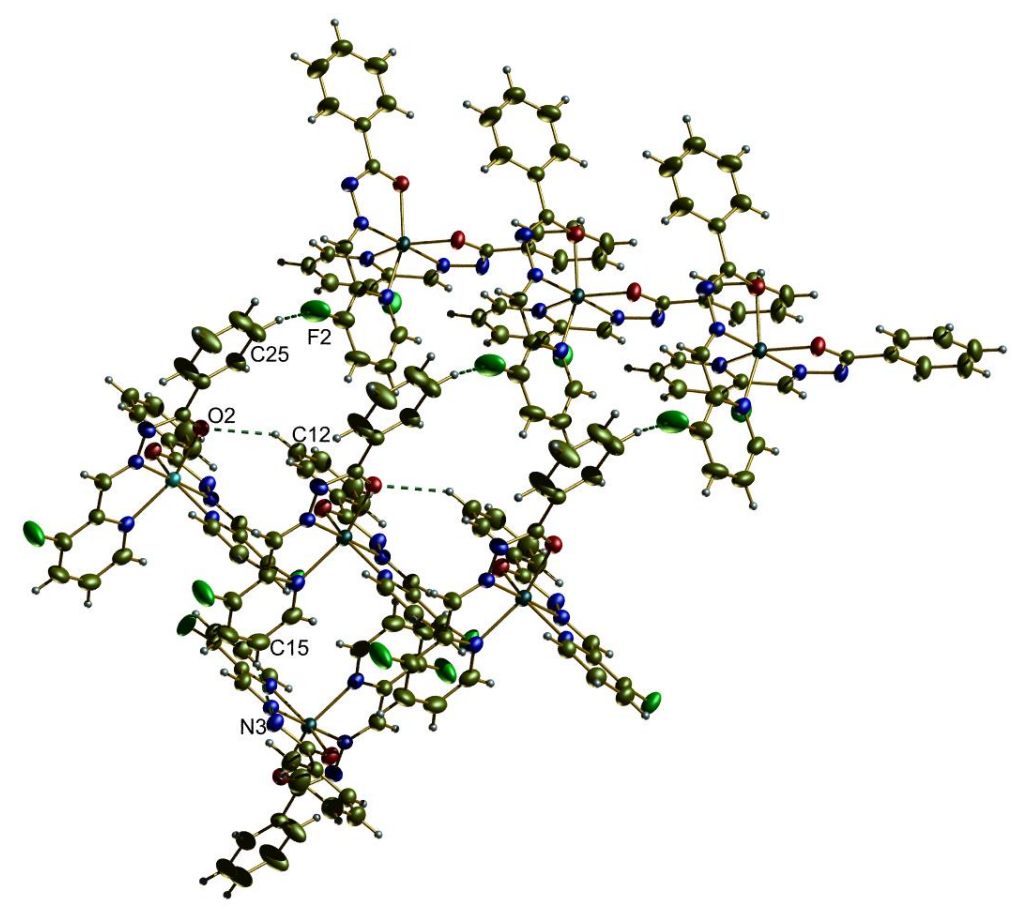

Fig. 4 Hydrogen Bonding $\mathrm{C}-\mathrm{H} \cdots \mathrm{N}, \mathrm{C}-\mathrm{H} \cdots \mathrm{O}$ and $\mathrm{C}-\mathrm{H} \cdots \mathrm{F}$

We could find intermolecular hydrogen bonding interactions namely $\mathrm{C}-\mathrm{H} \cdots \mathrm{N}, \mathrm{C}-\mathrm{H} \cdots \mathrm{O}$ and C-H $\cdots$ F (Fig. 4) are actually present in the structure and take part in linking the adjacent units with each other, propagating like a chain. These 1D supramolecular constructs are formed by medium strength $\mathrm{H}$-bonds and represent the main building blocks of the structure.

The packing of the molecules is also stabilized by some other weak intermolecular contacts $\mathrm{C}-$ $\mathrm{H}^{\cdots} \pi, \mathrm{C}-\mathrm{F} \cdots \pi$ and $\pi \cdots \pi$ interactions (Fig. 5) and are presented in Table S10. The $\pi$-stacking interactions found between the aromatic rings of adjacent molecules connect them in a head to tail fashion with a $\mathrm{C}_{\mathrm{g}}{ }^{\cdots} \mathrm{C}_{\mathrm{g}}$ contact distance of 3.7048(17) $\AA$. In addition to the weak $\pi$-stacking interactions, significant $\mathrm{C}-\mathrm{F} \cdots \pi$ and $\mathrm{C}-\mathrm{H}^{\cdots} \cdots \pi$ interactions further reinforce the unit cell packing (Fig. 6). 


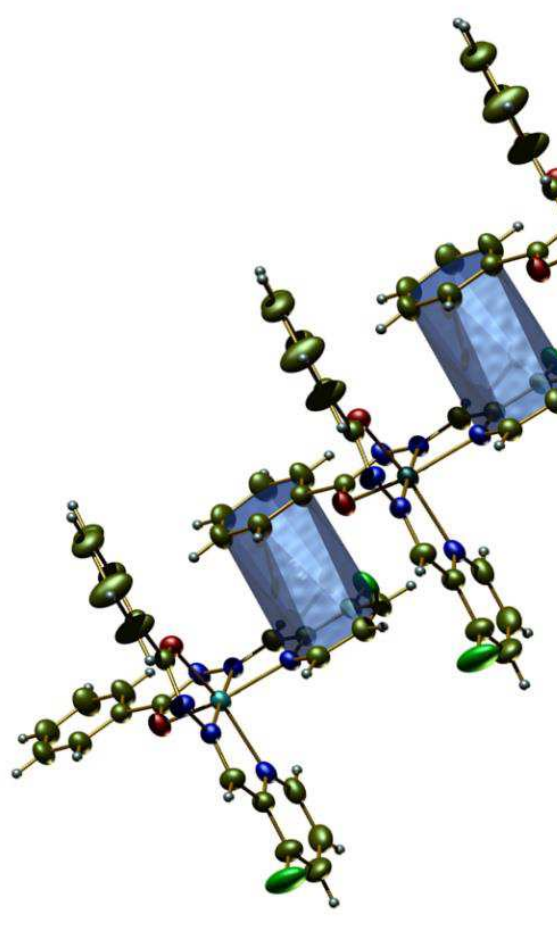

(a)

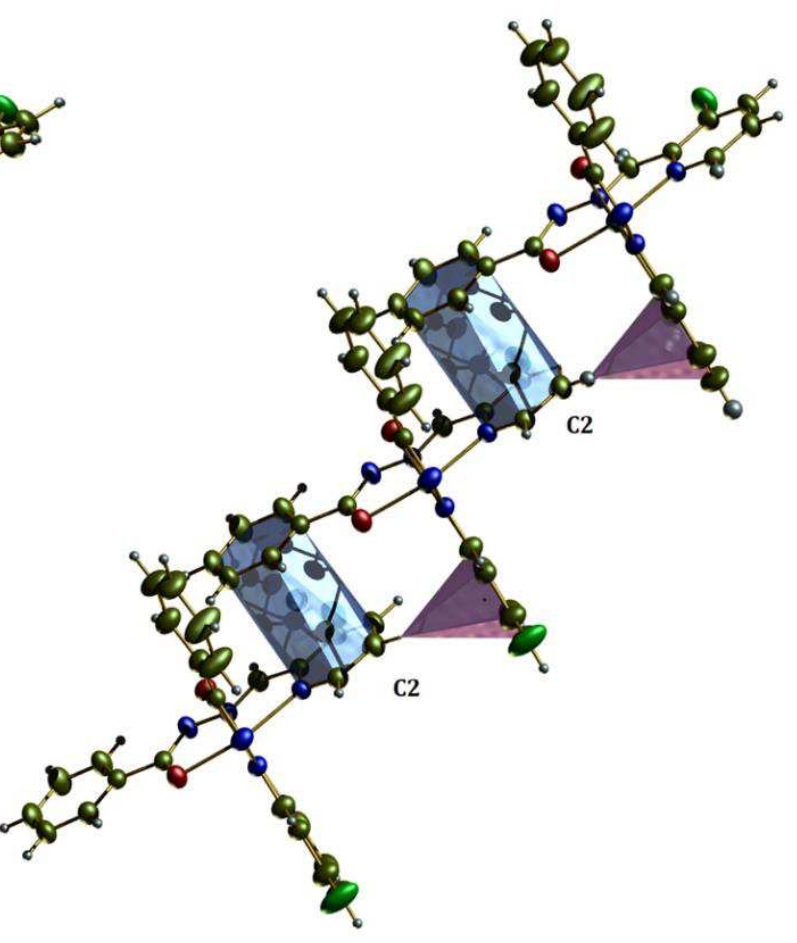

(b)

Fig. 5 a The $\pi \cdots \pi$ interactions in complex $5 \mathbf{b}$ C- $-H^{\cdots} \pi$ and $\pi-\pi$ interactions in complex 5

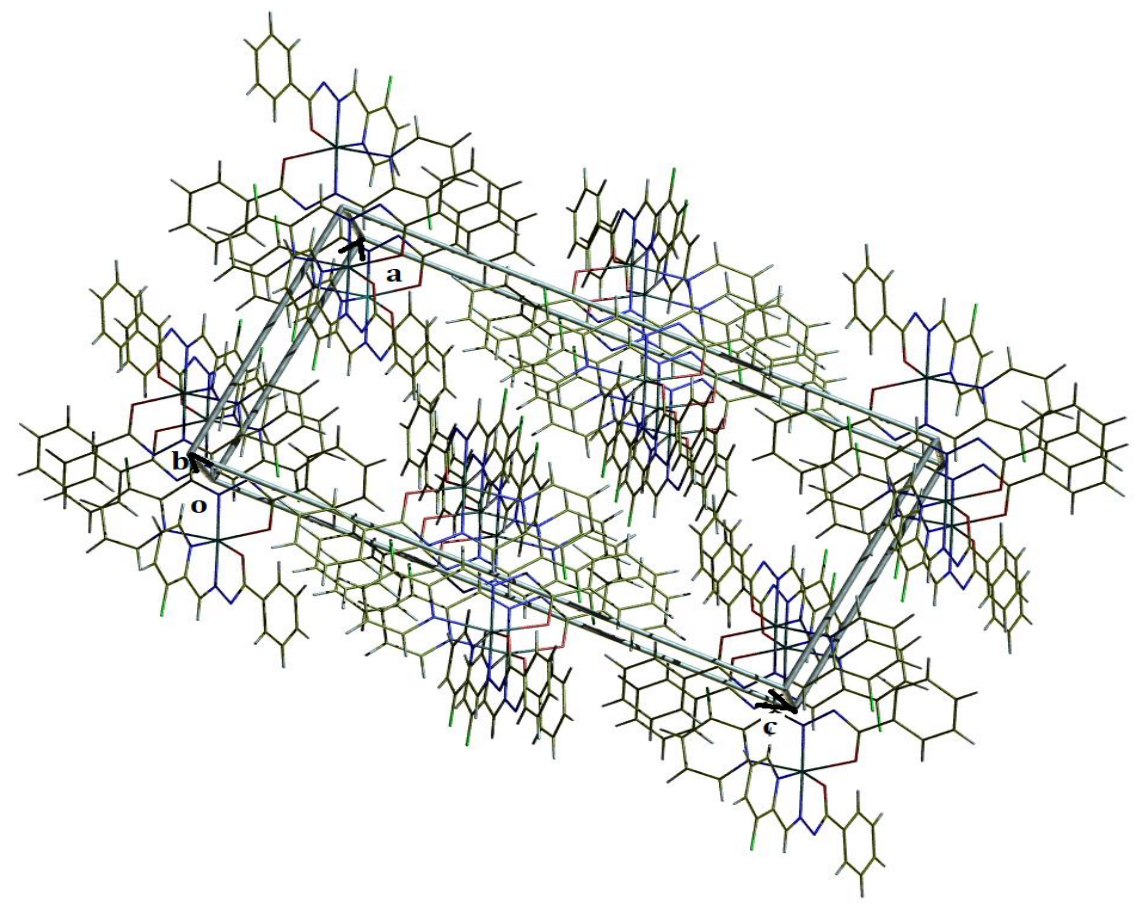

Fig .6 Unit Cell Packing 


\subsection{Hirshfeld surface analysis}

CIF from the SCXRD studies is used to map Hirshfeld surfaces with different functions. The surfaces are kept transparent so that we can easily observe the complexes. We get globularity and asphericity of the surfaces from the HSs. Globularity describes the deviation from spherical surface. Anisotropy of objects is obtained by term asphericity [52]. High value of asphericity is an indication of deviation from symmetry. With $d_{\text {norm }}$ function, deep red points are observed on the surface, which indicates strong hydrogen bonding interactions, while small red spots are the weak hydrogen bonding interactions. With the shape index function, some red-blue triangle regions (bow-tie patterns) are observed. This is due to the $\pi \cdots \pi$ stacking interactions. Curvedness function shows more flat or planar regions.

These interactions can be quantified with the help of 2D fingerprint regions. Each interaction can precisely analyse from decomposition plots (Fig. 8). Major contributions are from $\mathrm{H} \cdots \mathrm{H}$ interactions (40.6\%). Other significant interactions are C $\cdots \mathrm{H}(19.6 \%), \mathrm{F} \cdots \mathrm{H}(8.7 \%), \mathrm{C} \cdots \mathrm{C}$ $(7.4 \%), \mathrm{N} \cdots \mathrm{H}(7.4 \%)$ and $\mathrm{O} \cdots \mathrm{H}(5.7 \%)$. Comparative contributions of various interactions are shown in Fig. 9.
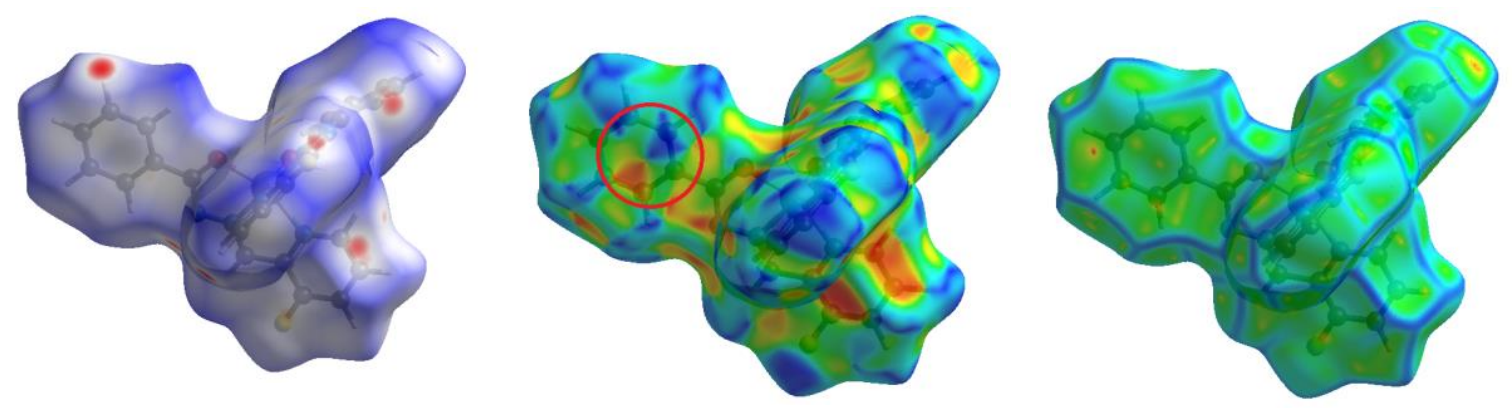

Fig. 7 Hirshfeld surfaces for $\left[\mathrm{Ni}(\mathrm{FPB})_{2}\right]$, mapped a) with $\mathrm{d}_{\text {norm }}$, b) shape-index and c) curvedness.

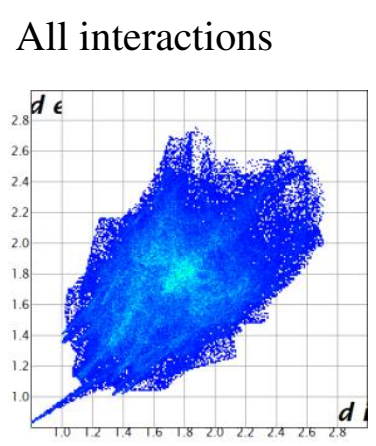

$\pi \cdots \pi / \pi \cdots \pi$

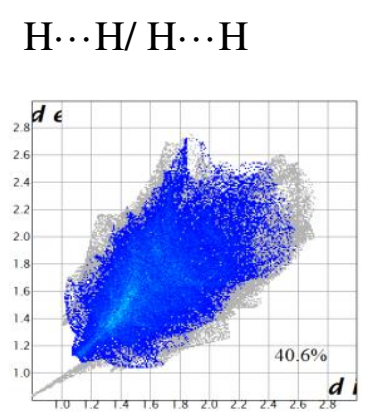

$\mathrm{N} \cdots \mathrm{H} / \mathrm{H} \cdots \mathrm{N}$
$\mathrm{C} \cdots \mathrm{H} / \mathrm{H} \cdots \mathrm{C}$

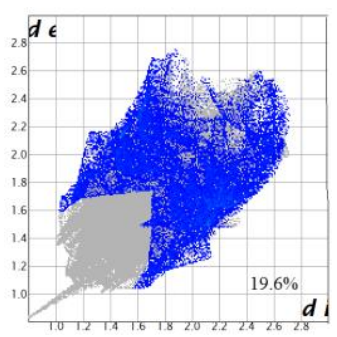

$\mathrm{O} \cdots \mathrm{H} / \mathrm{H} \cdots \mathrm{O}$
$\mathrm{F} \cdot \mathrm{H} / \mathrm{H} \cdots \mathrm{F}$

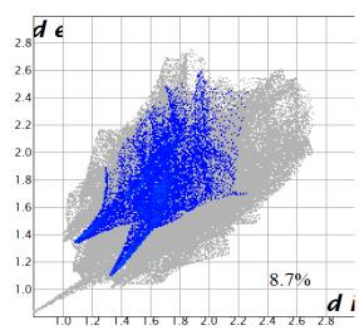

$\mathrm{F} \cdots \mathrm{C} / \mathrm{C} \cdots \mathrm{F}$ 

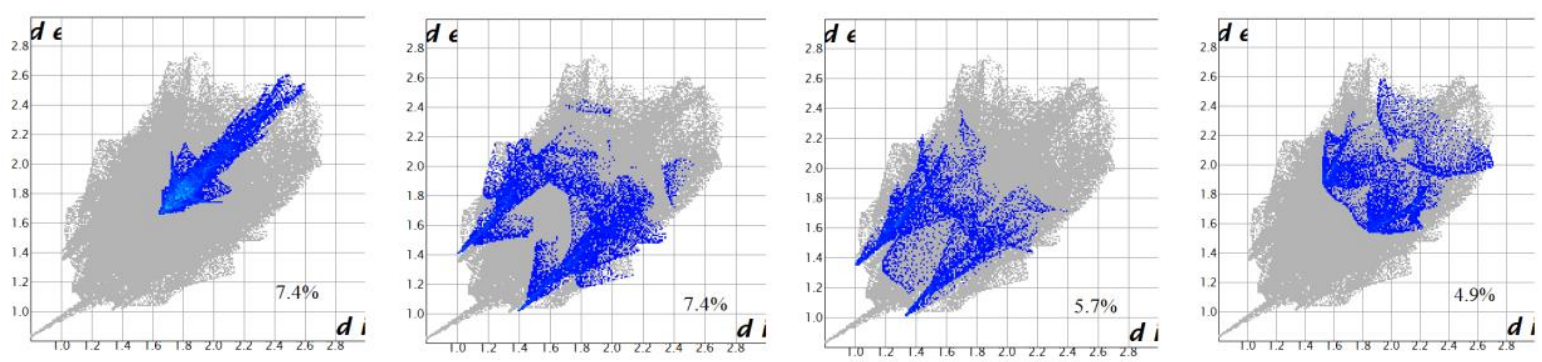

Fig. $82 \mathrm{D}$ finger print plots with $\mathrm{d}_{\mathrm{e}}$ and $\mathrm{d}_{\mathrm{i}}$ ranging from 1.0 to $2.8 \AA$ for $\left[\mathrm{Ni}(\mathrm{FPB})_{2}\right]$ and their major decomposition plots.

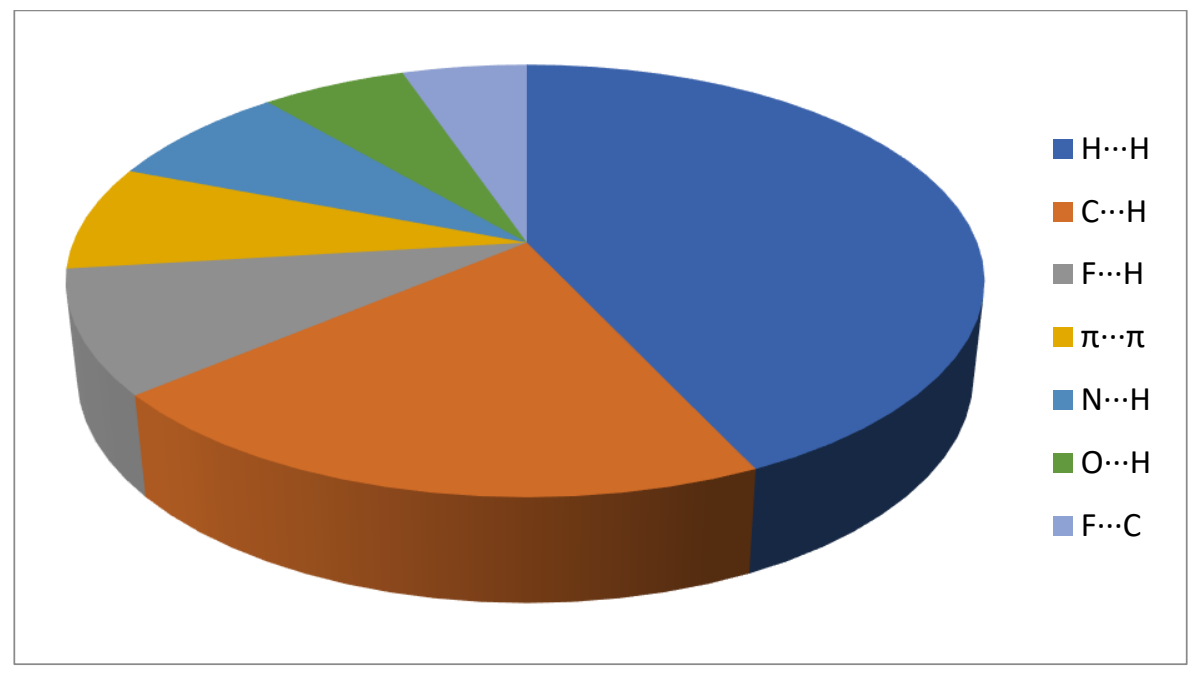

Fig. 9 Comparative contributions of various types of interactions in the Hirshfield surfaces.

\subsection{Quantum Chemical Analyses}

\subsubsection{NBO Analysis}

The optimized geometry of HFPB and the corresponding nickel complexes (1-5) with the original atom numbering scheme are given in Fig. 10. The results of the second orderperturbative energy analyses of the reported compounds are provided in Table S11.

NBOs of the proligand and the corresponding metal complexes are analyzed to predict possible inter- and intra-molecular interactions and to bring about an obsolete basis for the investigation of charge transfer or conjugative interactions in molecular systems [53,54]. For the HFPB precursor, the electron movement from the lone pair of $\mathrm{N} 3$ atom to the neighboring antibonding orbitals contributed the maximum towards stabilization energy; the $E^{(2)}$ of the interactions $\mathrm{LP}(1) \mathrm{N} 3\left(\mathrm{ED}_{\mathrm{i}}=1.65992 \mathrm{e}\right) \rightarrow \Pi^{*} \mathrm{~N} 1-\mathrm{C} 2\left(\mathrm{ED}_{\mathrm{j}}=0.18325 \mathrm{e}\right)$ and $\mathrm{LP}(1) \mathrm{N} 3\left(\mathrm{ED}_{\mathrm{i}}=1.65992 \mathrm{e}\right) \rightarrow$ $\Pi^{*} \mathrm{C} 4-\mathrm{O} 28\left(\mathrm{ED}_{\mathrm{j}}=0.26520 \mathrm{e}\right)$ were found to be 30.14 and $44.80 \mathrm{kcal} / \mathrm{mol}$, respectively. Moreover, it can be concluded that the charge delocalization over the pyridine ring had significant role in the lowering the stabilization energy. The resonance interactions 
corresponding to $\Pi \mathrm{C} 5-\mathrm{N} 13(2)\left(\mathrm{ED}_{\mathrm{i}}=1.73129 \mathrm{e}\right) \rightarrow \Pi^{*} \mathrm{C} 6-\mathrm{C} 9\left(\mathrm{ED}_{\mathrm{j}}=0.39814 \mathrm{e}\right)$ and $\Pi \mathrm{C} 7-\mathrm{C} 10$ (2) $\left(\mathrm{ED}_{\mathrm{i}}=1.66455 \mathrm{e}\right) \rightarrow \Pi^{*} \mathrm{C} 5-\mathrm{N} 13\left(\mathrm{ED}_{\mathrm{j}}=0.34762 \mathrm{e}\right)$ for HFPB were calculated and the stabilization energy; $E^{(2)}$ was found to be 23.90 and $24.31 \mathrm{kcal} / \mathrm{mol}$, respectively. A significant $\mathrm{n} \rightarrow \pi^{*}$ interaction (Table S1); LP(3) F26 $\left(\mathrm{ED}_{\mathrm{i}}=1.92819 \mathrm{e}\right) \rightarrow \Pi^{*} \mathrm{C6}-\mathrm{C} 9\left(\mathrm{ED}_{\mathrm{j}}=0.39814 \mathrm{e}\right)$ was calculated for HFPB and the corresponding $E^{(2)}$ value was found to be $17.40 \mathrm{kcal} / \mathrm{mol}$. Although the influence of electron delocalization in lowering the stabilization energy was determined to be smaller than the resonance interactions, as expected, the anomeric interactions contributed significantly towards the stabilization energy.

It is clear from the Table S11 that the resonance interactions have a dominant contribution on stabilization of the five Ni(II) complexes. The highest-energy interaction for complex 1 was determined to be $\mathrm{LP}(3) \mathrm{O} 18\left(\mathrm{ED}_{\mathrm{i}}=1.69338 \mathrm{e}\right) \rightarrow \mathrm{LP} *(5) \mathrm{Ni}\left(\mathrm{ED}_{\mathrm{j}}=0.80070 \mathrm{e}\right)$ with the $E^{(2)}$ value of $47.55 \mathrm{kcal} / \mathrm{mol}$. Furthermore, the charge transfer from the compound's main body to the $\mathrm{Ni}$ atom's empty "d" orbital was notable. For complex 1, the charge migration to LP*(5) Ni from each filled orbitals LP(1) N11 and LP(2) O14 were calculated with $E^{(2)}$ value of 33.88 and $30.78 \mathrm{kcal} / \mathrm{mol}$, respectively. Moreover, the charge flow around the hydrazide bond of the complex 1, П C15-N16 (2) $\rightarrow \Pi^{*} \mathrm{~N} 2-\mathrm{C} 12\left(E^{(2)}=32.97 \mathrm{kcal} / \mathrm{mol}\right)$, contributed significantly towards lowering of the stabilization energy. The chelation of HFPB towards the nickel center in complex 1 caused more charge flow from the substituted fluorine to the pyridine ring in comparison to the HFPB precursor and the interaction; $\mathrm{LP}(3) \mathrm{F} 17\left(\mathrm{ED}_{\mathrm{i}}=1.91318 \mathrm{e}\right) \rightarrow \Pi^{*} \mathrm{C} 3$ C5 $\left(\mathrm{ED}_{\mathrm{j}}=0.39768 \mathrm{e}\right)$ was determined with the $E^{(2)}$ value of $20.09 \mathrm{kcal} / \mathrm{mol}$. The counterpart interaction for complex 2 was determined for the interaction LP(3) F54 $\rightarrow \Pi^{*}$ C20-C22 with an energy of $9.16 \mathrm{kcal} / \mathrm{mol}$. In addition, the charge migration towards $\mathrm{Ni}$ atom from each of the bonding orbitals LP (2) O2, LP (1) N4, and LP (1) N28 for complex 2 were calculated with $E^{(2)}$ value of $13.24,19.88$, and $15.51 \mathrm{kcal} / \mathrm{mol}$, respectively. For complex 2 , the energy of the charge flow to antibonding orbital $\Pi^{*} \mathrm{O} 3-\mathrm{C} 10$ from the lone pair of $\mathrm{N} 9$ atom was found to be $21.68 \mathrm{kcal} / \mathrm{mol}$. The highest contribution towards stabilization energy of complex $\mathbf{3}$ is sourced from the interaction $\mathrm{LP}(3) \mathrm{O} 28\left(\mathrm{ED}_{\mathrm{i}}=1.68590 \mathrm{e}\right) \rightarrow \mathrm{LP} *(5) \mathrm{Ni}\left(\mathrm{ED}_{\mathrm{j}}=0.79811 \mathrm{e}\right)$ with $E^{(2)}=$ $47.25 \mathrm{kcal} / \mathrm{mol}$. However, various other interactions, LP (2) O28 $\rightarrow \Pi^{*} \mathrm{C} 29-\mathrm{O} 30\left(E^{(2)}=41.91\right.$ $\mathrm{kcal} / \mathrm{mol}), \Pi \mathrm{N} 4-\mathrm{C} 5 \rightarrow \Pi^{*} \mathrm{C} 3-\mathrm{N} 47\left(E^{(2)}=29.10 \mathrm{kcal} / \mathrm{mol}\right)$, and $\Pi \mathrm{C} 9-\mathrm{C} 11 \rightarrow \Pi^{*} \mathrm{C} 7-\mathrm{N} 14\left(E^{(2)}=\right.$ $28.56 \mathrm{kcal} / \mathrm{mol}$ ) being the highest energy contributions towards stabilization energy is determined for complex 3. For complex 4, the energies of the charge movement to the unoccupied " $d$ " orbital of Ni atom from each of the filled orbitals LP (1) N11, LP (2) O14, and LP (3) 018 were calculated with $E^{(2)}=37.39,37.83$, and $33.98 \mathrm{kcal} / \mathrm{mol}$, respectively. On the other hand, the charge migration to LP* (5) Ni atom from each filled orbitals LP (2) O2 and 
LP (1) N28 for complex 5 was determined and the energy was found to be 10.64 and 11.85 $\mathrm{kcal} / \mathrm{mol}$, respectively. Apart from the above mentioned interactions, the electron movement around the -N-N- linkage; $\Pi \mathrm{N} 8-\mathrm{C} 11(2) \rightarrow \Pi^{*} \mathrm{~N} 5-\mathrm{C} 7\left(E^{(2)}=15.44 \mathrm{kcal} / \mathrm{mol}\right)$ of complex 5 contributed the maximum towards the stabilization energy. The stabilisation energy for the charge transfer from the oxygen atom of complexes 1,2, and 4 considerably contributed to the lowering of the stability of these complexes as expected when considering the electron donating capabilities of the oxygen atom.

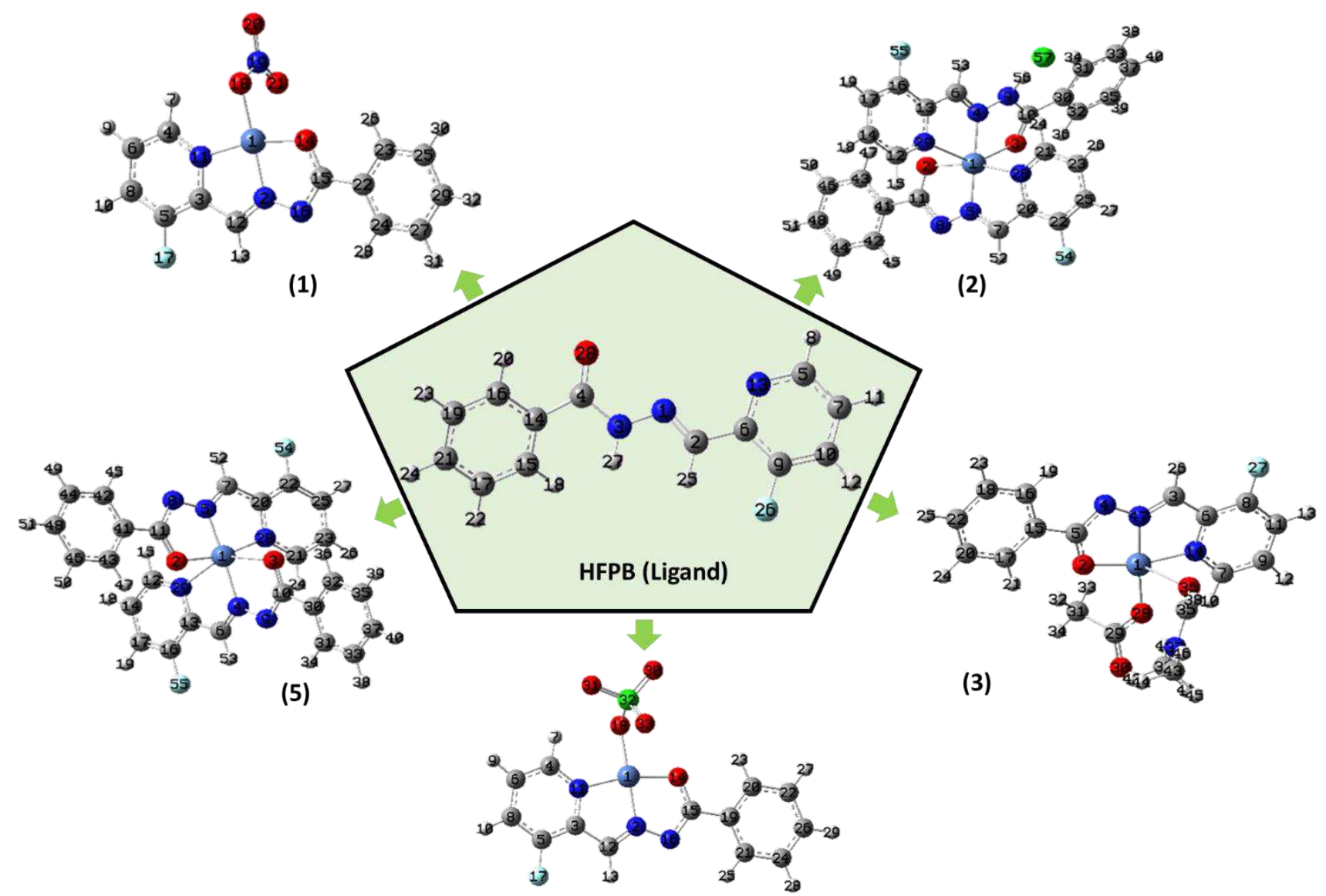

(4)

Fig. 10 The optimized structures of HFPB molecule and five Ni(II) complexes at B3LYP/6$31++\mathrm{G}(\mathrm{d}, \mathrm{p}) / \mathrm{LANL} 2 \mathrm{DZ}$ level

\subsubsection{Chemical reactivity and Frontier molecular orbitals}

In contemporary research, the electronic-structure-related quantum chemical parameters have been implemented successfully to evaluate the reactivity phenomenon of many kinds of chemical species which include a wide spectrum of molecules from basic systems $[55,56]$ to complex molecular structures [57,58]. All the calculated physical and QCPs of precursor HFPB and five $\mathrm{Ni}(\mathrm{II})$ complexes are given in Table 5. First and foremost, the inclusion of $\mathrm{Ni}$ atom reduces the reactivity of all complexes compared to the precursor HFPB. The frontier 
molecular energy parameters which include $\mathrm{E}_{\mathrm{HOMO}}, \mathrm{E}_{\mathrm{LUMO}}$ and $\Delta \mathrm{E}$ are some of the extensively used and significant quantum chemical parameters that intent to reduce the gap between experiment and theory. The value of $\mathrm{E}_{\mathrm{HO} о}$ of a molecule is an index that reflects the tendency of a molecule to lose electrons while the value of ELUMO reflects the tendency of a molecule to accept electrons. Higher the value of $\mathrm{E}_{\text {Hомо }}$ and $\mathrm{E}_{\mathrm{Lumo}}$ greater is the tendency of the molecule to lose and accept electrons respectively thereby, increasing the chemical reactivity. The HOMO electron densities of the ligand are distributed over the azomethine and the pyridine ring to which fluorine atom is attached while the LUMO electron densities are located throughout the molecule. The HUMO electron densities for all the complexes are concentrated more towards the metal center while the LUMO electron densities are mostly spread throughout the molecule. The $\Delta \mathrm{E}$ value indicates the level of hardness and softness and reflects the chemical stability of a molecule. A soft molecule will have a lower $\Delta \mathrm{E}$ value and will be more reactive compared to molecules having a higher $\Delta \mathrm{E}$ value. The value of $\Delta \mathrm{E}(\mathrm{L}-\mathrm{H})$ of the test molecules was determined and it decreases in the order $\Delta \mathrm{E}(\mathrm{L}-\mathrm{H})(\mathrm{eV})$ : HFPB $(4.308)>4$ $(3.178)>\mathbf{1}(3.170)>\mathbf{3}(3.056)>\mathbf{2}(2.711)>\mathbf{5}(2.587)$ which implies that the proligand HFPB would prefer to interact with the external chemical species more than the intramolecular interactions. The calculated $\omega, \omega^{+}, \omega^{-}$values decreases in the order:

$$
\begin{aligned}
& \omega(\mathrm{au}): \mathbf{4}(0.321)>\mathbf{1}(0.305)>\mathbf{2}(0.282)>\mathbf{5}(0.256)>\mathbf{3}(0.255)>\operatorname{HFPB}(0.168) \\
& \omega^{+}(\mathrm{au}): \mathbf{4}(0.232)>\mathbf{1}(0.218)>\mathbf{2}(0.205)>\mathbf{5}(0.184)>\mathbf{3}(0.177)>\operatorname{HFPB}(0.096) \\
& \omega^{-}(\mathrm{au}): \mathbf{4}(0.425)>\mathbf{1}(0.407)>\mathbf{2}(0.373)>\mathbf{3}(0.347)>\mathbf{5}(0.340)>\operatorname{HFPB}(0.259)
\end{aligned}
$$

The values of $\omega, \omega^{+}, \omega^{-}$for all the test compounds clearly indicates that HFPB molecule has the least electrophilic, electron donating, and electron accepting properties, whereas complex 4 has the most. The charge transfer capacities of the compounds were also determined, and they are found to be decreasing in the order; $\Delta \mathrm{N}(\mathrm{eV}): \mathbf{2}(3.367)>\mathbf{4}(3.317)>\mathbf{5}(3.281)>\mathbf{1}$ (3.239) > 3 (3.014) > HFPB (2.058). In accordance with the values of $\Delta \mathrm{N}$, the groups FPB and $-\mathrm{ClO}_{4}$ when chelated to $\mathrm{Ni}$ atom exhibited a higher charge transfer capacity in comparison to $\mathrm{NO}_{3}$ group. In all test compounds, the calculated electron donating power was found to be greater than the electron accepting power because of the strong electron donating groups containing an oxygen atom. 
Table. 5 The quantum chemical and physical parameters of HFPB molecule and five Ni(II) complexes at B3LYP/6-31++G(d,p)/LANL2DZ level

\begin{tabular}{lllllll}
\hline & HFPB & $\mathbf{1}$ & $\mathbf{2}$ & $\mathbf{3}$ & $\mathbf{4}$ & $\mathbf{5}$ \\
\hline $\mathrm{H}(-I)(\mathrm{eV})$ & -6.587 & -6.718 & -5.920 & -6.134 & -6.859 & -5.538 \\
$\mathrm{~L}(-A)(\mathrm{eV})$ & -2.279 & -3.548 & -3.209 & -3.078 & -3.681 & -2.950 \\
$\Delta \mathrm{E} \quad(\mathrm{L}-\mathrm{H})$ & 4.308 & 3.170 & 2.711 & 3.056 & 3.178 & 2.587 \\
$(\mathrm{eV})$ & & & & & & \\
$\mu(\mathrm{eV})$ & -4.433 & -5.133 & -4.565 & -4.606 & -5.270 & -4.244 \\
$\eta(\mathrm{eV})$ & 2.154 & 1.585 & 1.356 & 1.528 & 1.589 & 1.294 \\
$\omega(\mathrm{au})$ & 0.168 & 0.305 & 0.282 & 0.255 & 0.321 & 0.256 \\
$\omega^{+}(\mathrm{au})$ & 0.096 & 0.218 & 0.205 & 0.177 & 0.232 & 0.184 \\
$\omega^{-}(\mathrm{au})$ & 0.259 & 0.407 & 0.373 & 0.347 & 0.425 & 0.340 \\
$\Delta \mathrm{N}(\mathrm{eV})$ & 2.058 & 3.239 & 3.367 & 3.014 & 3.317 & 3.281 \\
$\mathrm{DM}($ debye $)$ & 4.761 & 7.671 & 7.858 & 5.714 & 8.513 & 5.910 \\
$\alpha(\mathrm{au})$ & 204.727 & 270.121 & 462.821 & 325.315 & 278.397 & 467.322 \\
\hline
\end{tabular}

The electrophilic and nucleophilic attack regions of precursor HFPB and five Ni(II) complexes are given in Fig. 11 through the HOMO, LUMO, and MEP densities. The constructed MEP surface diagrams helps us to visualize the charge distributions and charge related properties of the molecules. The MEP surface of the ligand clearly indicate the presence of Lewis base region (red and yellow coloured negative region) and is susceptible to electrophilic attack or coordination to metal centers. The blue-coloured region over the $\mathrm{NH}$ proton of the ligand stipulates the presence of a more electrophilic region. Moreover, the ESP plots of the ligand indicates its soft nature and the preference for NNO coordination. In complex 1, the most negative potential is over the oxygen atoms of the nitro group and the lattice water while in complex $\mathbf{2}$, it is located over the chloride ion which is present outside the coordination sphere. In complex $\mathbf{3}$, the negative potential is towards the carbonyl oxygen of the acetate group while a reduced electron density over the hydroxyl oxygen of the acetate group and the carbonyl oxygen of DMF is a clear indication of chelation with the metal centre. In complexes $\mathbf{4}$ and $\mathbf{5}$ there is an increase in electron density over the phenyl rings when compared to the ligand. 
HOMO

(5)

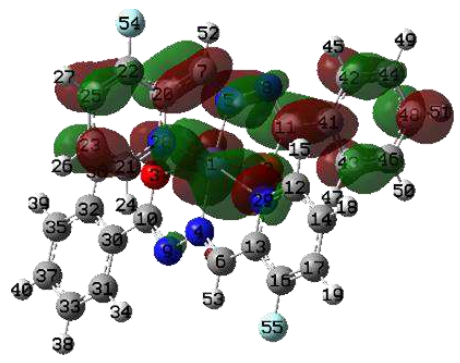

(4)

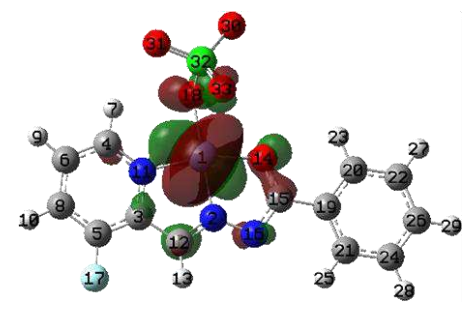

(3)

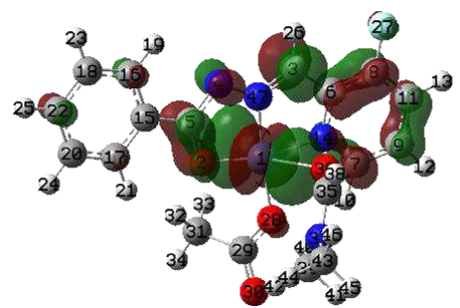

(2)

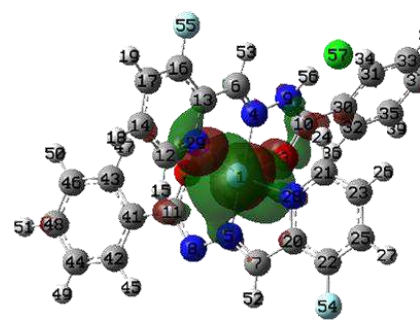

(1)

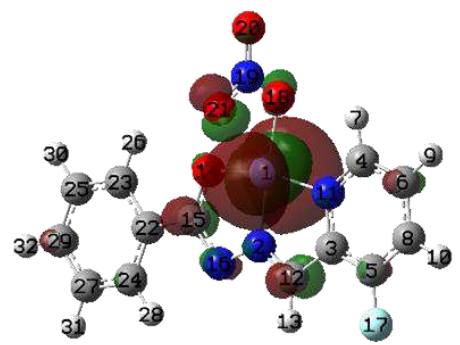

(HFPB)

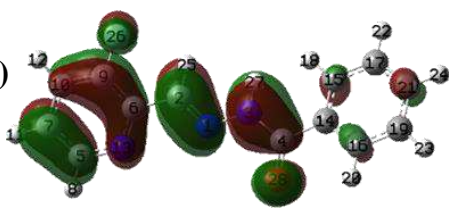

LUMO
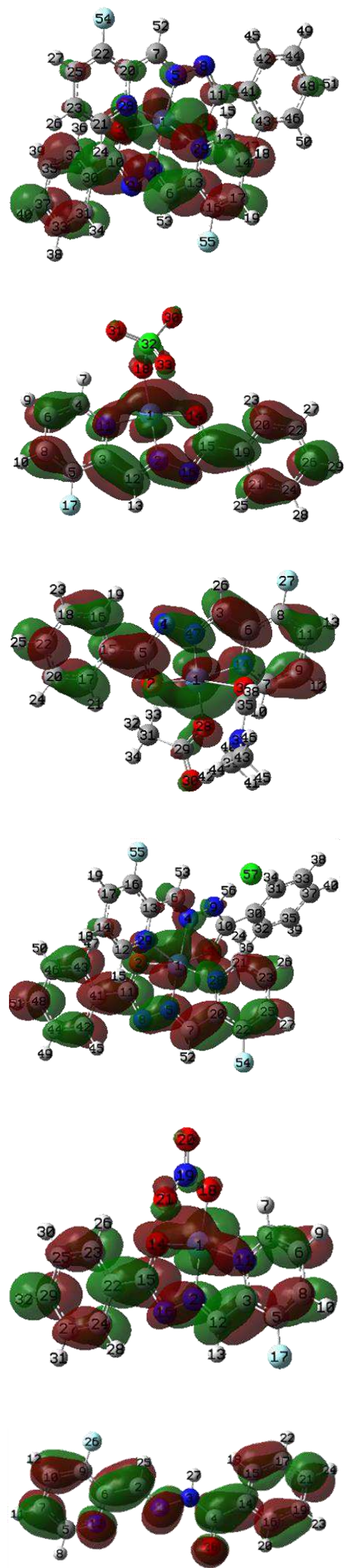

MEP
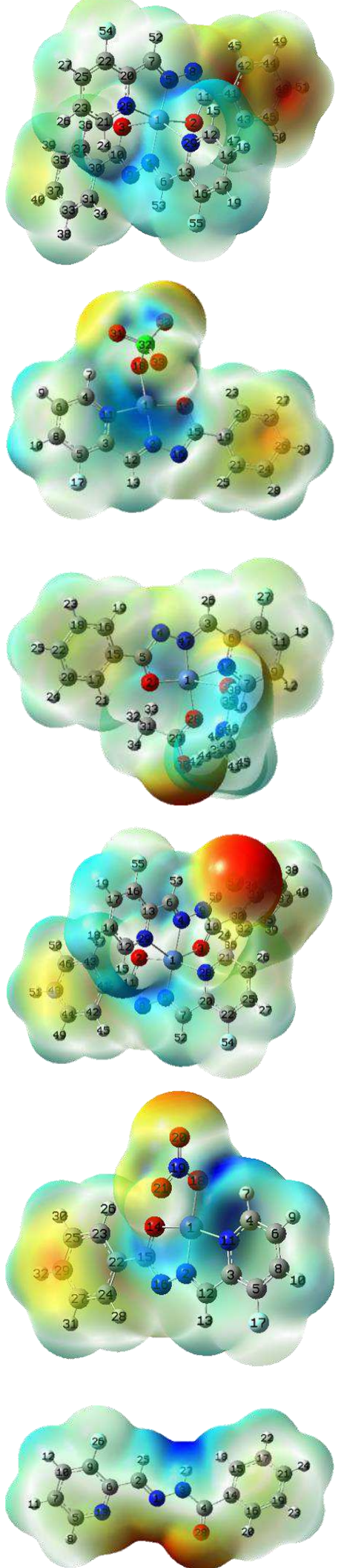

Fig. 11 HOMO \& LUMO (isoval:0.02) and MEP (isoval:0.0004) for HFPB molecule and five $\mathrm{Ni}(\mathrm{II})$ complexes at B3LYP/6-31++G(d,p)/LANL2DZ level. 


\subsection{DNA binding studies}

\subsubsection{Electronic absorption titration}

Fixed amount $\left(63 \mu \mathrm{L}, 10^{-5} \mathrm{M}\right)$ of metal complex (5) was titrated with increasing amounts of CT-DNA in the range from 5 to $50 \mathrm{mM}$. The distinct bands at about $276 \mathrm{~nm}$ are attributed to intra ligand $\pi-\pi^{*}$ transitions and the lower energy bands at about $372 \mathrm{~nm}$ are assigned to the ligand-to-metal charge transfer transitions. The absorption spectrum clearly shows that addition of DNA yields a significant amount of hypochromism and a large red shift in the UV absorption spectrum of the test molecule at 276 and $372 \mathrm{~nm}$ pertaining to intra ligand and LMCT transition bands respectively (Fig. 12a). These spectral characteristics reveal an intercalative mode of binding of the complex to DNA helix through a strong stacking between aromatic hydrazone ligands and DNA base pairs [59].

In the present study, the intrinsic binding constant $\left(\mathrm{K}_{\mathrm{b}}\right)$ for the complex (5) is calculated following the hypochromism of LMCT band observed at $372 \mathrm{~nm}$. The $\mathrm{K}_{\mathrm{b}}$ value of complex 5 is found to be $0.8418 \times 10^{4} \mathrm{M}^{-1}$ (Fig. 12b), however, the observed $\mathrm{K}_{\mathrm{b}}$ value of the complex is much less than that of the classical intercalators like $\mathrm{EB}\left(\mathrm{K}_{\mathrm{b}}=7.7 \times 10^{7} \mathrm{M}^{-1}\right)$, confirming a nonclassical mode of intercalation, similar to other reported compounds in the literature (Table 6) [60]. The octahedral complex binds to DNA in three dimensions, the extended aromatic surface of the Ni complex due to the presence of two hydrazone moieties intercalate into DNA base pairs and the $\pi^{*}$ orbital of the intercalated complex would be expected to couple with $\pi$ orbitals of base pairs resulting in hypochromism.

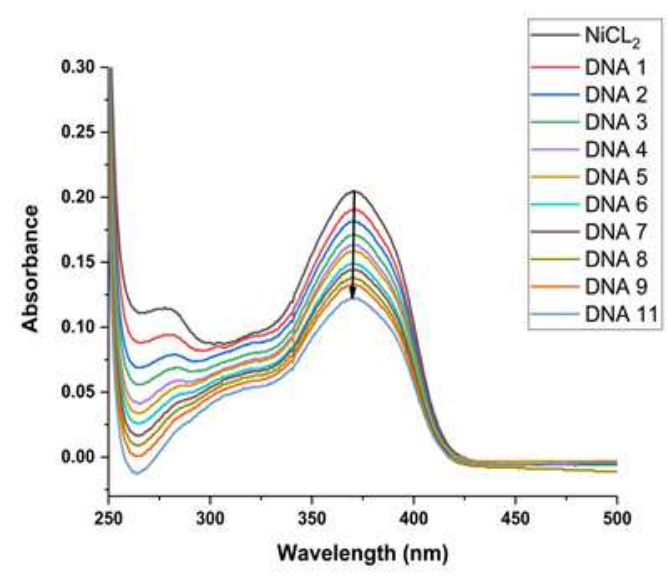

(a)

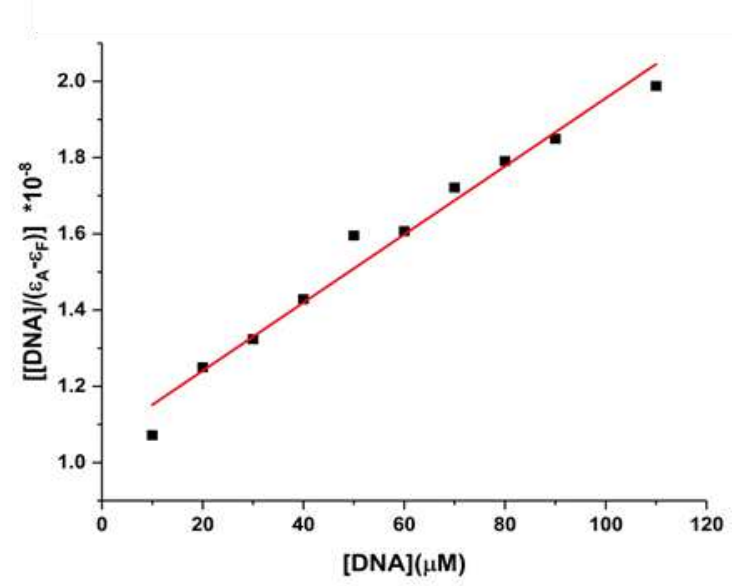

(b) 
Fig. 12 a Electronic absorption spectra of $\mathrm{Ni}$ (II) complex 5 upon incremental addition of CTDNA; b The plot of $[D N A] /\left[\varepsilon_{\mathrm{A}}-\varepsilon_{\mathrm{F}}\right]$ versus [DNA] for the titration of CT-DNA with the complex 5.

\subsubsection{Fluorescence spectroscopic studies}

Ethidium bromide (EB) demonstrates a dramatic enhancement of its fluorescence when complexed to DNA and in the present study EB replacement studies by the addition of test molecule (complex 5) as a quencher have been carried out to support the binding of complex to DNA.

Results of fluorescence measurements obtained for the present system (5) are consistent with a mechanism for quenching that does not involve appreciable displacement of ethidium from the nucleic acid. Instead, ethidium ion and the complex simultaneously bind to DNA forming an adduct and the enhanced hydrophobicity due to the flanking aromatic rings in the DNA bound complex would be expected to perturb DNA helix thereby displacing EB [61]. Fig. 13a shows the emission spectra of the DNA-EB system with incremental addition of the metal complex. The addition of the test molecule to the DNA-bound EB solution caused an appreciable reduction in emission intensity and the fluorescence data were analysed using the Stern-Volmer equation (Eq. 3, Fig. 13b).

The binding strength of the test molecule was also evaluated in terms of equilibrium DNA binding constant, $\mathrm{K}_{\mathrm{b}}$, employing Scatchard equation, which includes number of binding sites, by regression analysis (Fig. 13c).

$$
\frac{\log \left[F_{0} F\right]}{F}=\log K_{b}+n \log [Q]
$$

The $\mathrm{K}_{\mathrm{sv}}, \mathrm{Kq}, \mathrm{K}_{\mathrm{b}}$ and $\mathrm{n}$ values for the interactions of $\mathbf{5}$ with DNA are shown in Table 6 . The experimental results show that $\mathrm{Ni}$ (II) complex displays strong binding propensity with DNA which also validates the electronic absorption spectral results. 


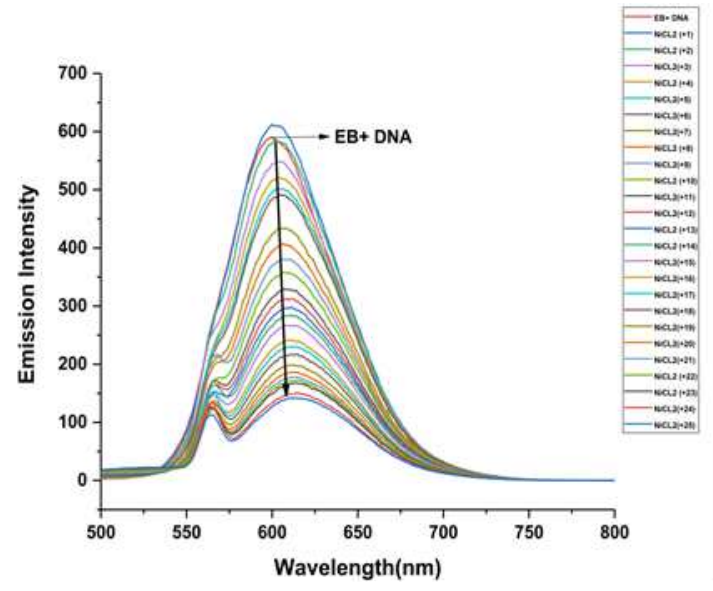

(a)

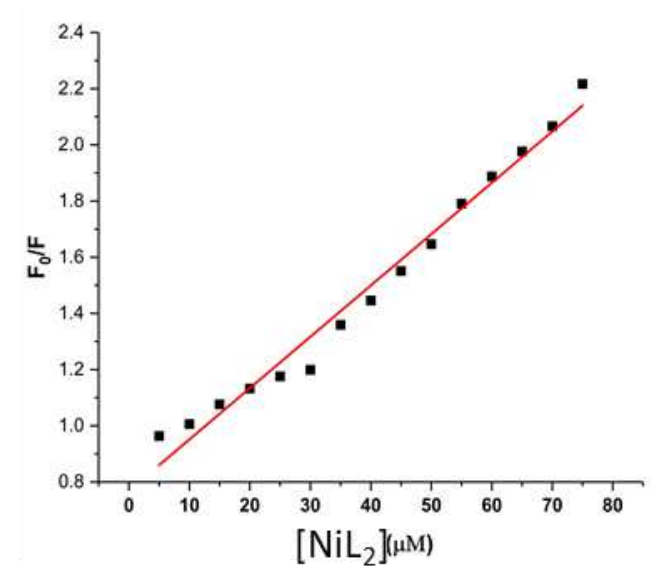

(b)

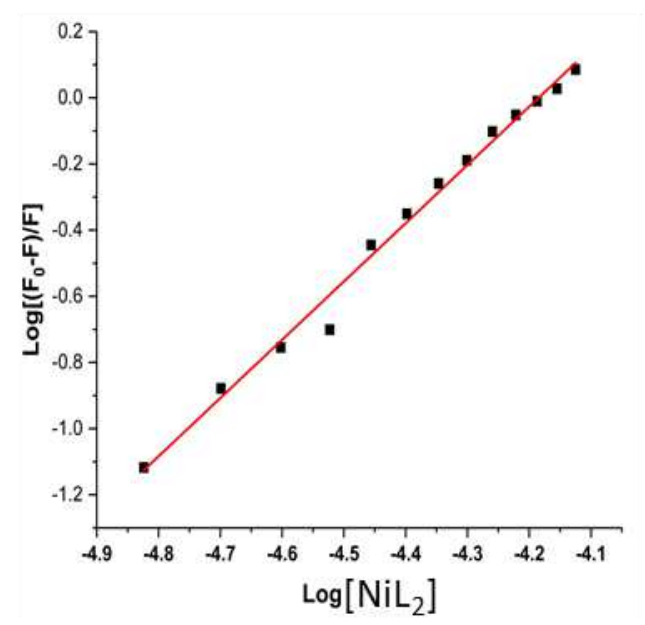

(c)

Fig. 13 a Emission spectra of DNA-EB system in the absence and presence of complex 5; b Stern-Volmer plot of fluorescence titrations of the complex 5 with CT-DNA; c Scatchard plot of fluorescence titrations of the complex 5 with CT-DNA.

Table. 6 Absorption and Emission data

\begin{tabular}{|c|c|c|c|c|c|c|c|}
\hline \multicolumn{8}{|c|}{ Absorption Titration } \\
\hline \multirow[t]{2}{*}{ Complex } & \multicolumn{2}{|c|}{$\lambda_{\max }$} & \multirow[t]{2}{*}{$\Delta \lambda(\mathbf{n m})$} & \multirow[t]{2}{*}{$\mathrm{H} \%$} & \multirow[t]{2}{*}{$\mathbf{K}_{\mathbf{b}}\left(\mathbf{M}^{-1}\right)$} & \multirow[t]{2}{*}{$\Delta \mathbf{G}$} & \\
\hline & Free & Bound & & & & & \\
\hline 5 & 372 & 376 & 4 & -49 & $0.8418 \times 10^{4}$ & $-22,397$ & \\
\hline \multicolumn{8}{|c|}{ Emission Titration } \\
\hline Complex & Ksv x $10^{4}$ & ${ }^{a} \mathbf{R}^{2}$ & $\mathbf{K}_{\mathbf{b}}\left(\mathbf{M}^{-1}\right)$ & ${ }^{b} \mathbf{R}^{2}$ & $\mathrm{Kq} \times 10^{12}\left(\mathrm{M}^{-1}\right)$ & $\Delta \mathbf{G}$ & $\begin{array}{l}\text { Number of } \\
\text { binding } \\
\text { sites (n) }\end{array}$ \\
\hline 5 & 1.827 & 0.980 & $2.3498 \times 10^{4}$ & 0.990 & 1.827 & $-24,934$ & 1.76 \\
\hline
\end{tabular}

$\mathrm{H}=$ '-'Hypochromism, '+' 'hyperchromism, $^{\mathrm{a}} \mathrm{R}$ is the correlation coefficient for the $\mathrm{K}_{\mathrm{SV}}$ values 
${ }^{b} \mathrm{R}$ is the correlation coiefficent for the $\mathrm{K}_{\mathrm{b}}$ values

\subsection{Molecular docking with DNA}

Molecular docking studies helps us to determine the interactions of the investigated chemical species with biological macromolecules at the molecular level. This method can convey striking information regarding various biological applications and hence leading to the development of a potential drug candidate. The target protein PDB ID:4REA, a DNA constructspecific nuclease involved in the processing of biological macromolecule is present in human DNA interchain cross-links (ICLs). This protein is associated with nuclease 1 FAN1. FAN1 maintains genomic stability and prevents tissue reduction in multiple organs. In some cancer types, it provides anti-cancer drug resistance caused by cross-links between DNA strands [62]. The binding energies of the investigated compounds 1-5 according to their preferred location on human DNA (PDB ID: 4REA) and the interaction types with the nucleotides at the binding sites resulting from their interaction with DNA are given in Table 7. The binding modes of compounds 1-5 interacting with DNA are shown in Fig. 14.

Table. 7 Molecular docking result data of compound 1-5 with 4REA.

\begin{tabular}{|c|c|c|c|c|c|c|}
\hline Comp. & $\begin{array}{l}\text { Binding energy } \\
\text { (kcal/mol) }\end{array}$ & H-bond & Polar & Hydrophobic & $\pi-\pi$ & $\begin{array}{l}\text { Halogen- } \\
\text { bond }\end{array}$ \\
\hline 1 & -6.23 & THR555 & GLU559 & $\begin{array}{l}\text { MET558 } \\
\text { ARG955 } \\
\text { LEU916 } \\
\text { SER915 } \\
\text { LEU870 } \\
\text { CYS871 } \\
\text { PHE951 } \\
\text { PHE866 } \\
\text { PHE660 }\end{array}$ & $\begin{array}{l}\text { PHE866 } \\
\text { PHE951 }\end{array}$ & - \\
\hline 2 & -4.95 & THR555 & ARG952 & $\begin{array}{l}\text { CYS871 } \\
\text { CYS659 }\end{array}$ & PHE866 & LEU868 \\
\hline 3 & -6.12 & CYS871 & $\begin{array}{l}\text { ARG952 } \\
\text { SER915 }\end{array}$ & $\begin{array}{l}\text { PHE866 } \\
\text { MET558 }\end{array}$ & $\begin{array}{l}\text { PHE866 } \\
\text { PHE951 }\end{array}$ & PHE951 \\
\hline 4 & -6.29 & $\begin{array}{l}\text { THR555 } \\
\text { MET558 }\end{array}$ & $\begin{array}{l}\text { GLU559 } \\
\text { ARG952 }\end{array}$ & $\begin{array}{l}\text { PHE866 } \\
\text { CYS659 } \\
\text { CYS871 } \\
\text { PHE660 }\end{array}$ & $\begin{array}{l}\text { PHE660 } \\
\text { PHE866 }\end{array}$ & - \\
\hline 5 & -4.63 & SER616 & $\begin{array}{l}\text { ARG668 } \\
\text { ARG672 }\end{array}$ & LEU612 & - & $\begin{array}{l}\text { MET558 } \\
\text { SER557 }\end{array}$ \\
\hline
\end{tabular}

According to the docking results, the binding energies of the 1-5 complexes with human DNA are quite strong. The highest binding energy is obtained for complex $\mathbf{4}$. The test compounds 
exhibited various kinds of non-covalent interactions like hydrogen bonding, polar, hydrophobic, $\pi-\pi$ interactions and halogen bonds with DNA and got effectively intercalated between the DNA base pairs. Hydrogen bonding contributes significantly towards binding energy. It is clear from Table 4 that complex $\mathbf{4}$ forms two hydrogen bonds with DNA base pairs which results in high binding energy. Moreover, hydrophobic interactions of the test compounds with DNA are quite prominent with the amino acid residues of the target proteins. The test compounds also exhibit stacking interactions with DNA due to the extended aromatic surfaces that can effectively form $\pi-\pi$ interactions with DNA base pairs [63].

When the interaction poses of the investigated complexes and target proteins representing DNA binding were examined, it was observed that the hydrazone ligands forming the skeletal structure were in approximately the same region of the DNA groove. The nitrogen and oxygen atoms of hydrazone ligands are involved in strong hydrogen bonding interactions with the nucleotides of DNA. Phenyl groups in all compounds favor $\pi-\pi$ stacking interactions as well as hydrophobic and polar interactions with amino acid residues. Moreover, the fluorine atom present in the ligand is found to form halogen bonds with the DNA base pairs. Altogether, hydrogen bonding, hydrophobic interactions, $\pi-\pi$ stacking and halogen bonding contribute significantly towards the binding of the respective metal complexes with DNA. 

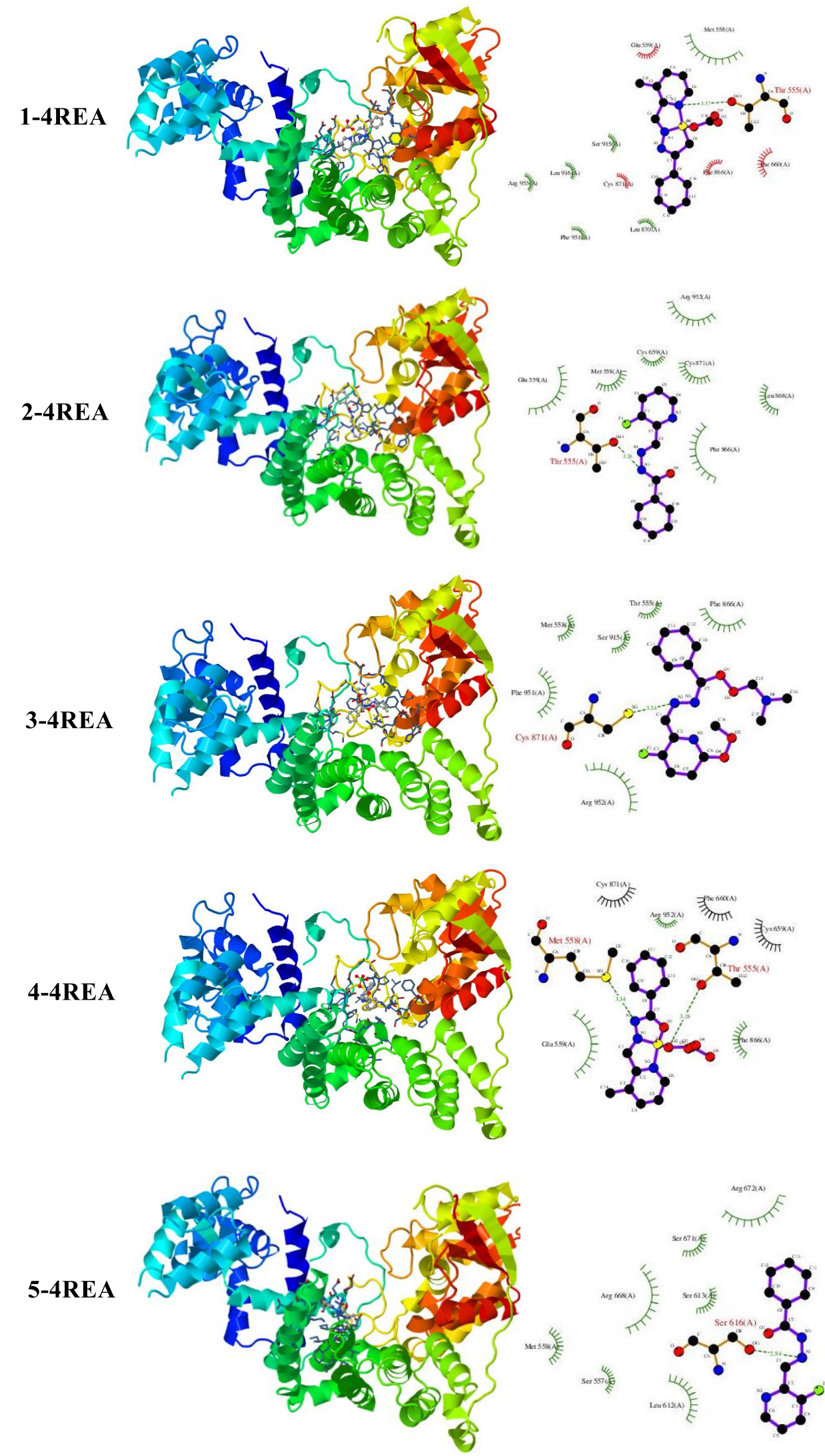

Fig. 14 Molecular docking pose showing potential interactions of complexes 1-5 with 4REA. 


\section{Conclusion}

The synthesis, characterization, and theoretical studies of some novel $\mathrm{Ni}$ (II) chelates of a heterocyclic based tridentate aroylhydrozone are reported. Various characterization techniques including IR, UV, thermogravimetric analyses and single crystal XRD studies were used to identify the products. A detailed characterization of the newly developed complexes is presented by combining experimental and high-level theoretical calculations. The used computational methods could provide good structural descriptions of the reported novel coordination materials and are found to be consistent with the experimental results. Molecular structure of complex 5 has been elucidated by single crystal X-ray diffraction studies and is found to have a distorted octahedral geometry. The presence of lattice water in complex $\mathbf{1}$ has been justified by TGA data. Hirshfeld surface analysis of the complex $\mathbf{5}$ was also performed to explore the contributions of intermolecular interactions towards crystal packing. UV-Vis and fluorescence titration studies demonstrated intercalative mode of binding between complex $\mathbf{5}$ and DNA. Additionally, molecular docking studies reveals the existence of various interactions like hydrogen bonding, hydrophobic, $\pi-\pi$ stacking and halogen bonding between the metal complex and DNA base pairs.

\section{Supplementary data}

Appendix A. Supplementary data

CCDC 2111685 contains the supplementary crystallographic data for [Ni(FPB $\left.)_{2}\right](5)$. The data can be obtained free of charge via www.ccdc.cam.ac.uk/conts/retrieving.html or from the Cambridge Crystallographic Data Centre, 12 Union Road, Cambridge CB2 IEZ, UK; fax: (+44) 1223-336-033; or e-mail: deposit@ccdc.cam.ac.uk.

\section{Acknowledgement}

The authors are thankful to the Sophisticated Analytical Instrument Facility, Cochin University of Science \& Technology, Kochi-22, India for single crystal XRD measurements, analytical and spectral data. The authors would also like to thank Centre for Research, Christ (Deemed to be University), Bangalore, India for the facilities that greatly assisted the research.

\section{Declarations}

\section{Conflicts of interest}


There are no conflicts of interest

\section{References}

1. E. K. Barefield, D. H. Busch, S. M. Nelson, Q. Rev. Chem. Soc. 22, 457 (1968).

2. R. I. Haines, A. McAuley, Coord. Chem. Rev. 39, 77 (1981).

3. M. del Mar Conejo, J. Cantero, A. Pastor, E. Álvarez, A. Galindo, Inorg. Chim. Acta 470, 113 (2018).

4. E. Pilichos, E. Spanakis, E.-K. Maniaki, C. P. Raptopoulou, V. Psycharis, M. M. Turnbull, S. P. Perlepes, Magnetochemistry. 5, 39 (2019).

5. T. A. Ajayeoba, O. Folorunso Akinyele, A. O. Ayeni, I. J. Olawuni, Am. J. Appl. Chem. 7, 64 (2019).

6. P. E. M. Siegbahn, S.-L. Chen, R.-Z. Liao, Inorganics 7, 95 (2019).

7. G. Genchi, A. Carocci, G. Lauria, M. S. Sinicropi, and A. Catalano, Int. J. Environ. Res. Public Health 17, 679 (2020).

8. L. Sacconi, R. Ballhausen, Public Health 69, 3 (1955).

9. A. K. Datta, C. W. Riggs, M. J. Fivash, K. S. Kasprzak, Chem.-Biol. Interact. 79, 323 (1991).

10. P. Yang, L. L. Zhang, Z. Z. Wang, D. D. Zhang, Y. M. Liu, Q. S. Shi, X. B. Xie, J. Inorg. Biochem. 203, 110919 (2020)

11. T. M. Asha, M. R. P. Kurup, Polyhedron 169, 151 (2019).

12. N. A. Mathews, A. Jose, M. R. P. Kurup, J. Mol. Struct. 1178, 544 (2019).

13. J. Kalia, R. T. Raines, Angew. Chem. Int. 47, 7523 (2008).

14. N.A. Mangalam, S. Sivakumar, S.R. Sheeja, M.R.P. Kurup, E.R.T. Tiekink, Inorg. Chim. Acta 362 4191-4197 (2009).

15. S.R. Sheeja, N.A. Mangalam, M. Sithambaresan, M.R.P.Kurup, G. Serdaroğlu, S. Kaya, J. Mol. Struct. 1245, 131001 (2021).

16. N.A. Mangalam, S. Sivakumar, M.R.P. Kurup, E. Suresh, Spectrochim. Acta A 75, 686 (2010).

17. V. Velezheva, P. Brennan, P. Ivanov, A. Kornienko, S. Lyubimov, K. Kazarian, B. Nikonenko, K. Majorov, A. Apt, Bioorganic Med. Chem. Lett. 26, 978 (2016).

18. G. A. A. Al-Hazmi, K. S. Abou-Melha, N. M. El-Metwaly, I. Althagafi, F. Shaaban, M. G. Elghalban, M. M. El-Gamil, Appl. Organomet. Chem. 34, e5408 (2020)

19. S.R. Sheeja, N.A. Mangalam, M.R.P. Kurup, Y.S. Mary, K. Raju, H.T. Varghese, C.Y. Panicker, J. Mol. Struct. 97336 (2010)

20. Y. Nair, M. Sithambaresan, M. R. P. Kurup, Acta Crystallogr. E 68, (2012). 
21. SMART and SAINT, Area Detector Software Package and SAX Area Detector Integration Program, Bruker Analytical X-ray; Madison, WI, USA, 1997.

22. G.M. Sheldrick, ActaCryst. C71 3 (2015)

23. K. Brandenburg, Diamond Version 3.2g, Crystal Impact GbR, Bonn, Germany, 2006.

24. M. Spackman and D. Jayatilaka, CrystEngComm. 11, 19 (2009).

25. A. D. Becke, Chem. Phys. 98, 5648 (1993).

26. L. C, Y. W, P. RG, Phys. Rev. B Condens. Matter 37, 785 (1988).

27. M. J. Frisch, G. W. Trucks, H. B. Schlegel, G. E. Scuseria, M. A. Robb, J. R. Cheeseman, G. Scalmani, V. Barone, B. Mennucci, G. A. Petersson, H. Nakatsuji, M. Caricato, X. Li, H. P. Hratchian, A. F. Izmaylov, J. Bloino, G. Zheng, J. L. Sonnenberg, M. Hada, M. Ehara, K. Toyota, R. Fukuda, J. Hasegawa, M. Ishida, T. Nakajima, Y. Honda, O. Kitao, H. Nakai, T. Vreven, J. A. Montgomery, Jr., J. E. Peralta, F. Ogliaro, M. Bearpark, J. J. Heyd, E. Brothers, K. N. Kudin, V. N. Staroverov, T. Keith, R. Kobayashi, J. Normand, K. Raghavachari, A. Rendell, J. C. Burant, S. S. Iyengar, J. Tomasi, M. Cossi, N. Rega, J. M. Millam, M. Klene, J. E. Knox, J. B. Cross, V. Bakken, C. Adamo, J. Jaramillo, R. Gomperts, R. E. Stratmann, O. Yazyev, A. J. Austin, R. Cammi, C. Pomelli, J. W. Ochterski, R. L. Martin, K. Morokuma, V. G. Zakrzewski, G. A. Voth, P. Salvador, J. J. Dannenberg, S. Dapprich, A. D. Daniels, O. Farkas, J. B. Foresman, J. V. Ortiz, J. Cioslowski, and D. J. Fox, Gaussian 09W, Revision D.01, Gaussian, Inc, Wallingford CT, (2013)

28. P. J. Hay, W. R. Wadt, J. Chem. Phys. 82, 299 (1998).

29. M. J. Frisch, J. A. Pople, J. S. Binkley, M. J. Frisch, J. A. Pople, J. S. Binkley, J. Chem. Phys. 80, 3265 (1984).

30. T. Clark, J. Chandrasekhar, G. W. Spitznagel, P. V. R. Schleyer, J. Comput. Chem. 4, 294 (1983).

31. T. Koopmans, Physica. 1, 104 (1934).

32. R. G. Parr, R. G. Pearson, J. Am. Chem. Soc. 105, 7512 (2002).

33. R. G. Pearson, Proc. Natl. Acad. Sci. U.S.A 83, 8440 (1986). 
34. Robert G. Parr, László v. Szentpály, and Shubin Liu, J. Am. Chem. Soc. 121, 1922 (1999).

35. José L. Gázquez, Andrés Cedillo, and A. Vela, J. Phys. Chem. A. 111, 1966 (2007).

36. Badhin Gómez, N. V. Likhanova, M. A. Domínguez-Aguilar, R. Martínez-Palou, and Alberto Vela, José L. Gázquez, J. Phys. Chem. B. 110, 8928 (2006).

37. J. P. Foster, F. Weinhold, J. Am. Chem. Soc 102, 7211 (1980).

38. A. E. Reed, R. B. Weinstock, F. Weinhold, J. Chem. Phys. 83, 735 (1998).

39. GaussView 6.0.16, Gaussian, Inc, Wallingford CT, 2016.

40. Z. Bikadi, E. Hazai, J. Cheminformatics. 1, 1 (2009).

41. R. Huey, G. M. Morris, A. J. Olson, and D. S. Goodsell, J. Comput. Chem. 28, 1145 (2007).

42. W. J. Geary, Coord. Chem. Rev. 7, 81 (1971).

43. P.F. Rapheal, E. Manoj, M.R.P. Kurup, H.-K. Fun, J. Mol. Struct. 1237, 130362 (2021).

44. P. Singh, D. P. Singh, K. Tiwari, M. Mishra, A. K. Singh, V. P. Singh, RSC Adv. 5, 45217 (2015).

45. V. Stefov, V. M. Petruševski, B. Šoptrajanov, J. Mol. Struct. 293, 97 (1993).

46. P.R. Satheesh Chandran, U.S. Soumya Mol, R. Drisya, M.R. Sudarsanakumar, M.R.P. Kurup, J. Mol. Struct. 1137, 396 (2017)

47. B. S. Garg, M.R.P. Kurup, S. K. Jain, Y. K. Bhoon, Transit. Met. Chem. 16, 111 (1991).

48. N.A. Mangalam, M.R.P. Kurup, Spectrochim. Acta A Mol. Biomol. Spectrosc. 78, 926 (2011).

49. M. Kuriakose, M.R.P. Kurup, E. Suresh, Struct. Chem. 18579 (2007)

50. N. Mathew, M. Sithambaresan, M.R.P. Kurup, Spectrochim. Acta A Mol. Biomol. Spectrosc. 79, 1154 (2011)

52. S. S. Sreejith, A. Nair, V. A. Smolenski, J. P. Jasinski, M. R. P Kurup, Inorganica Chim. Acta 469, 264 (2018). 
53. G. Serdaroğlu, Res. Chem. Intermed. 46, 961 (2019).

54. M. Elik and G. Serdaroğlu, Cumhuriyet Science J. 38, 138 (2017).

55. G. Serdaroğlu, Int. J. Quantum Chem. 111, 3938 (2011).

56. G. Serdaroğlu, Int. J. Quantum Chem. 111, 2464 (2011).

57. R. Junejo, N. S. Jalbani, S. Kaya, G. Serdaroglu, S. Şimşek, S. Memon, Separ. Sci. Tech. (2021).

58. J. M. Jacob, M. R. P. Kurup, K. Nisha, G. Serdaroğlu, S. Kaya, Polyhedron. 189, 114736 (2020).

59. H. Wu, X. Huang, J. Yuan, F. Kou, G. Chen, B. Jia, Y. Yang, Y. Lai, Z. Naturf. B J.Chem. Sci. 65, 1334 (2010).

60. R. F. Pasternack, M. Caccam, B. Keogh, T. A. Stephenson, A. P. Williams, E. J. Gibbs, J. Am. Chem. Soc. 113, 6835 (1991).

61. P. Uma Maheswari, M. Palaniandavar, J. Inorg. Biochem. 98, 219 (2004).

62. Q. Zhao, X. Xue, S. Longerich, P. Sung, Y. Xiong, Nat. Commun. 5, 1 (2014).

63. S. Erkan, J. Mol. Struct. 1189, 257 (2019). 


\section{Supplementary Files}

This is a list of supplementary files associated with this preprint. Click to download.

- SupportingInformationYNNipaper.docx

- checkcif.pdf

- nil2.txt 